\title{
Simulation and control of Thermally Activated Building Systems (TABS)
}

\author{
Joaquim Romaní ${ }^{1}$, Alvaro de Gracia ${ }^{2}$, Luisa F. Cabeza ${ }^{1{ }^{*}}$ \\ ${ }^{1}$ GREA Innovació Concurrent, Universitat de Lleida, Edifici CREA, Pere de Cabrera s/n, 25001, Lleida, \\ Spain. \\ ${ }^{2}$ Departament d'Enginyeria Mecanica, Universitat Rovira i Virgili, Av. Paisos Catalans 26, 43007 \\ Tarragona, Spain. \\ *Corresponding author: Tel: +34.973.00.35.76. Email: Icabeza@diei.udl.cat
}

\begin{abstract}
Buildings account for a significant amount of global energy use and $\mathrm{CO}_{2}$ emissions. Thermally Activated Building Systems (TABS) are a technology with potential for significantly reducing buildings energy use. TABS are heating and cooling systems that are integrated in the building structure. They mainly exchange heat through radiation and are able to store heat in the building thermal mass. TABS high thermal mass and their interaction with the building structure make their energy evaluation and design process difficult. Development of simulation models has been essential to study the design and control of TABS. Control of TABS is challenging due to the slow response time and storage capacity. A lot of research has been conducted to develop control strategies that fully exploit its energy saving potential and that maximise the use of renewable energies. This paper summarizes the main characteristics of TABS and presents the developed simulation models and control strategies.
\end{abstract}

Keywords: Thermally Activated Building Systems (TABS), building, modelling, control

\section{Introduction}

On the last decades there has been much concern on the energy consumption and greenhouse gases emissions. According to the International Energy Agency (IEA) [1] buildings account for $32 \%$ of global energy use and almost $10 \%$ of total direct energy-related $\mathrm{CO}_{2}$ emissions. Including electricity generation emissions (plus district heat), buildings are responsible for just over $30 \%$ of total end-use energy-related $\mathrm{CO}_{2}$ emissions. Consequently there is a great potential on energy use reduction in the building sector.

Within this context Thermally Activated Building Systems (TABS) is a promising technology that can track its origin back to the Chinese kang and dikang [2], the Roman hypocaust [3] or the Korean ondol [4]. Radiant floor heating was introduced to United States on the 1930's and in the 50's and 60's to central Europe, although problems were found due to poorly insulated buildings which led to too high surface temperatures [5]. A new trend was started on the 90s with the extension of radiant floor for cooling and the introduction of concrete cores for heating and cooling $[6,7]$. 
TABS main advantages are high thermal inertia, big surfaces and radiative nature. TABS are used for peak load shaving, and shifting energy consumption to high efficiency or low energy cost periods $[7,8]$. The use of big surfaces allows significant heat exchange with a small temperature gradient, making TABS a technology with potential for the use of low grade energy sources $[7,9]$. TABS radiative nature can improve comfort conditions $[10,11]$, operative temperatures are better managed and noises and draft caused by ventilation are reduced.

The high thermal inertia of TABS has dynamic effects that are difficult to calculate using steady state assumptions. Transient calculations are required for performance analysis and sizing of TABS $[12,13]$. It also makes TABS control difficult $[14,15]$ as its response time is slow and heating or cooling loads cannot be dealt instantaneously. Furthermore, TABS cannot deal with humidity thus they need to be coupled to any ventilation system. Coordination of TABS and ventilation systems is indispensable for good energy performance of buildings $[10,16]$.

Much research has been conducted around TABS as it is summarized on some reviews. Rhee and Kin [6] presented an historical review on TABS research. In contrast there are reviews on some specific subjects of TABS. In this context $\mathrm{Xu}$ et al. [9] presented a review on pipeembedded systems coupled to low grade energy sources, and a review on air based TABS, referred as hollow core slabs, which is focused on design and calculation methods [17]. Similarly Zhao et al. [18] reviewed the application of radiant cooling to large spaces while others critically review heat transfer coefficients [19] or TABS coordination with ventilation [20]. Despite all these research, there is not a clear nomenclature for TABS [10]. This paper reviews TABS generalities, the simulation models developed and the control strategies proposed. Moreover, a summary of the different nomenclature existent in the literature is presented.

\section{TABS generalities}

\subsection{Definition}

TABS are building elements that are actively used for heat transfer and heat storage. Water pipes or air ducts are embedded in the building surfaces or in the building structure to work as heat exchangers transferring heat to the building rooms and storing thermal energy into the structure. TABS do not only supply or extract heat but directly affect on building thermal performance. The temperature of TABS surface is regulated, which modifies the heat gains through the structure and causes a direct heat exchange with the building structure.

\subsection{Working principles}

TABS have big surfaces that are kept to a certain temperature to heat or cool spaces. Heat is mostly exchanged to other room surfaces by radiation but heat is also exchanged to room air by convection. Heat transfer coefficients of radiation and convection $[19,21]$ show the significant heat exchange due to radiation. The radiative nature of TABS and its influence on room surface temperatures makes essential to use Mean Radiant Temperature (MRT) and operative temperature to study comfort given by TABS [22,5]. TABS directly influencing on operative temperature can give better comfort conditions by maintaining lower operative temperatures in summer and higher operative temperature in winter $[10,23,24]$. 
Only sensible heat can be exchanged with TABS, humidity cannot be regulated with these systems, hence ventilation is required to deal with latent load. Nevertheless, ventilation is always needed for hygienic reasons $[25,26]$. However, as most heat load is dealt by TABS, ventilation systems only need to supply the minimum air change ratio for hygienic conditions, then fan and ducts can be reduced in size resulting in savings in energy consumption, installation cost and space [27]. Reducing the ventilation system can also improve comfort as there is less risk of discomfort by draft and noises $[5,28]$. In addition, TABS reduce ventilation loses as operative temperature is kept at comfort range with room air at higher temperature in summer and at lower temperature in winter, leading to more savings in ventilation. For cooling, TABS ventilation can be necessary to avoid condensation issues $[16,27,29]$ as surface temperatures might go below dew point in hot humid climates. Coordination between TABS and ventilation system is essential to reduce energy consumption and keep comfort conditions $[10,30]$.

Depending of its design, TABS can have high thermal mass, especially for systems embedded in the core of slabs. The thermal mass allows TABS to buffer the room temperature fluctuation by storing or releasing heat from the slabs. The energy lost or absorbed during the buffering is managed in other periods $[7,23,31]$, normally shifting to energy efficient periods. As a result chillers and boilers can be downsized thanks to peak load being reduced and redistributed. Thermal mass allows TABS to be operated in off peak modes, adding further economic saving to the previous energy savings [7,32-34]. However, TABS have long response times which will not allow dealing with instantaneous heat loads. Control strategies for building incorporating TABS have to be carefully designed and temperature fluctuations need to be admitted [32,3537].

By using the building structure, TABS have big surfaces which allow for significant heat transfer even for small temperature gradient between the fluid and the room operative temperature. The required low temperature gradient allows high temperature for cooling and low temperature for heating, which improves the efficiency of chillers and boilers and enables the use of low grade energy sources $[9,23,27,30,33]$. TABS peak load shifting ability helps to compensate the limited time availability of some renewable energy sources, such as night-time cooling or solar radiation, because energy can be stored when the source is available then the inertia of the slab buffers changes in the rooms. This increases the utilization of renewable energy and further increases economic savings. The low temperature gradient also has the advantage of causing an effect of self-control in TABS. A slight variation in room temperature results in a significant variation of heat flux which might even get to change operation mode if room temperature exceeds supply temperature $[7,5]$.

TABS require an adequate building insulation and building thermal mass, and its performance is synergistic with building thermal performance [7,24,33]. A good control of heat gains is also important, especially those caused by solar gains [30], within this context the use of automated solar blinds is usually recommended in buildings equipped with TABS. Finally, TABS cooling and heating capacities depend on the position of the active surface (floor, ceiling or wall) and the operation mode [27]. 


\subsection{Types of TABS and nomenclature in literature}

A lot of research has been done around TABS but the nomenclature is still heterogeneous [10]. There are different types of TABS depending on their intended operation mode, position and working fluid. However, the labelling of similar systems can vary significantly between authors. The following sections present the different types of TABS and Table 1 summarizes the diverse nomenclature and acronyms found in the literature.

\subsubsection{Radiant floor}

Radiant floors are light-weight TABS placed above the floor structure. A layer of insulation separates the structure from the pipes, which are embedded in a thin layer of concrete and covered with a screed layer, as shown in Figure 1. Heat flux is mainly transferred between the pipes and the floor surface. It is commonly assumed that the surface between the radiant floor and the structure is adiabatic. The main use of radiant floor is heating but also cooling has been used with success.

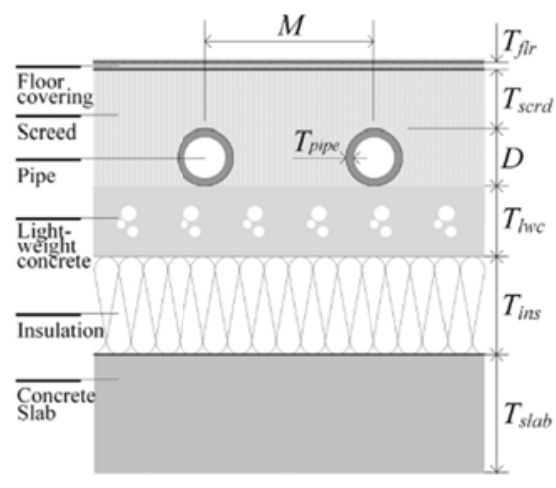

Figure 1: Radiant floor structure [38]

\subsubsection{Radiant ceiling}

Radiant ceilings are light-weight TABS placed at the lower surface of ceilings. The pipes can be embedded into the slab very near to the lower surface. They can also be positioned into a layer separated from the ceiling with insulation or on suspended ceiling which might create an air chamber between the ceiling and the panels. Figure 2 shows different configuration of radiant ceilings.

A common assumption is that radiant ceilings only exchange heat through the lower surface. The heat is only exchanged with the room and the contact between the radiant ceiling and the structure is considered adiabatic. Radiant ceiling systems are applied mainly for cooling but they can also be found for heating applications.
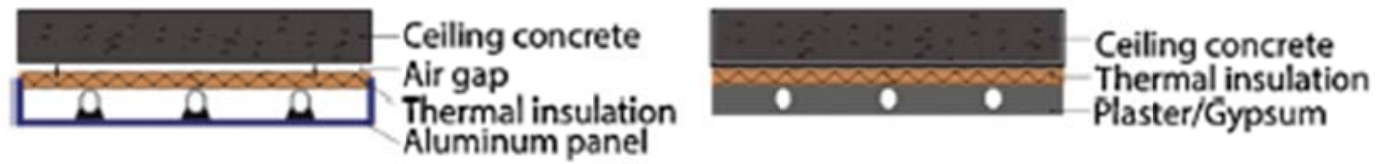

Figure 2: Radiant ceilings: bottom slab embedded pipes (left) [39], suspended ceiling panel (middle) and embedded pipes insulated from ceiling slab (right) [40]

\subsubsection{Hollow core slabs}

Hollow core slabs are heavy weight TABS that use the empty cores of prefabricated concrete slabs to circulate air. The ends of cores are closed and connected with holes creating and air 
path, a scheme of a concrete core is shown in Figure 3. Hollow core slabs are mainly used for cooling, night time ventilation with outdoor air is a typical use and an application for freecooling. The air circulation through the cores can also be used for room ventillation.

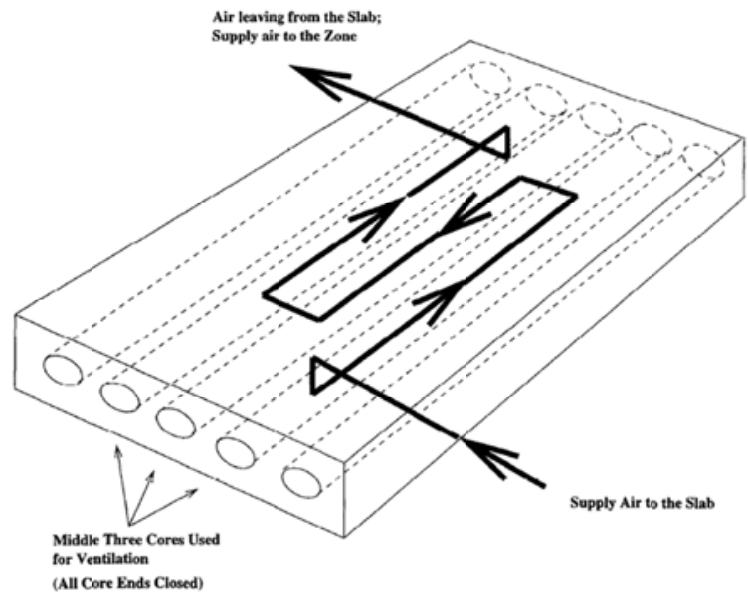

Figure 3: Hollow core slab [41]

\subsubsection{Concrete core}

Concrete core are heavy weight TABS were water pipes are embedded deep on the concrete slab. Figure 4 shows the structure of a concrete core which consists in a deck slab, positioned between stories. They can provide either heating or cooling having heat flux to both upper top surface, as radiant floor, and/or to the bottom surface, as radiant ceiling. Depending on the purpose of the design, insulation can be used to ensure heat flux through only one surface.

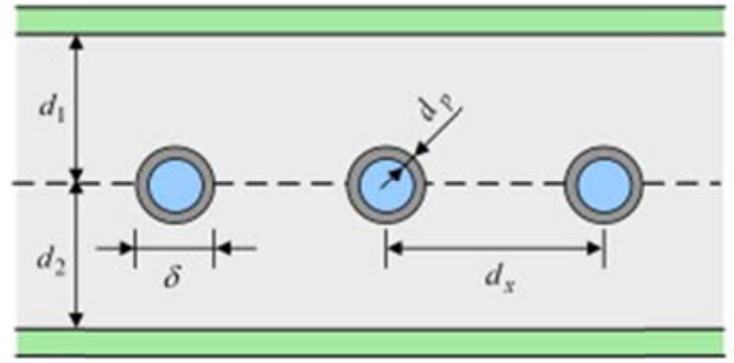

Figure 4: Concrete core [15]

\subsubsection{Pipe-embedded envelope}

Pipe embedded envelopes are heavy weight TABS that have its pipes circuits inside walls and roofs of the building in contact with outdoor ambient, an example of pipe-embedded envelope is shown in Figure 5. They can provide active cooling or heating to the indoor space but they are also used to reduce the influence of external climate by maintaining a section of the wall at a constant temperature. 


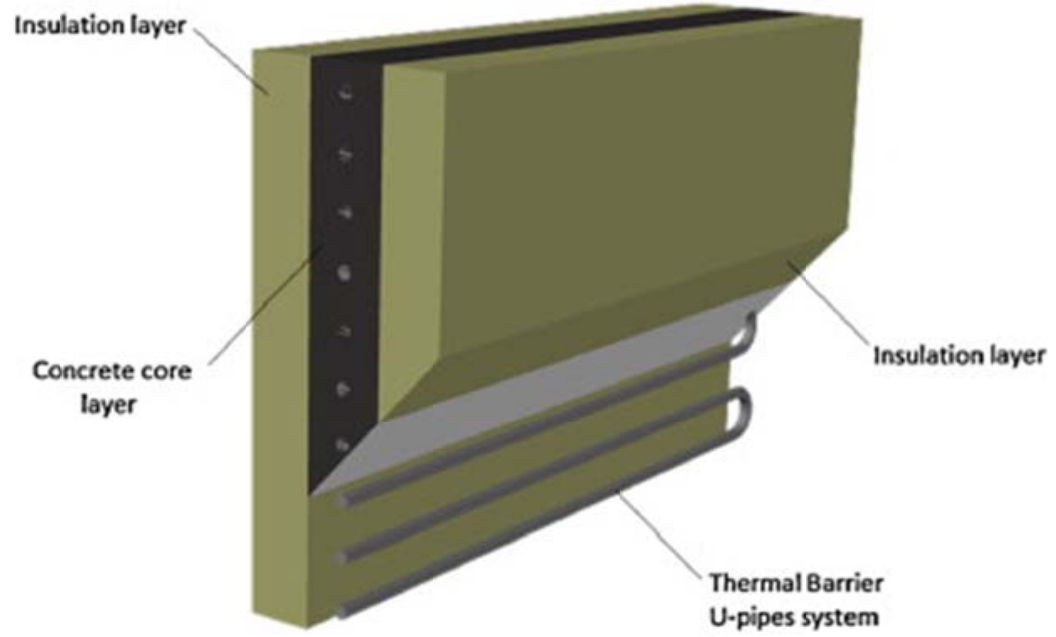

Figure 5: Pipe-embedded envelope [42] 
Table 1: TABS nomenclature ( ${ }^{*}$ Usually TABS is used as sole reference for concrete core slabs)

\begin{tabular}{|c|c|c|c|}
\hline Type & Specific nomenclatures & Acronym & Associated papers \\
\hline \multirow[t]{6}{*}{ Radiant floor } & Concrete slab floor & - & {$[43]$} \\
\hline & Floor heating & - & {$[44,45]$} \\
\hline & In floor radiant systems & - & {$[29]$} \\
\hline & Radiant cooling/heating & - & {$[6,46]$} \\
\hline & Radiant floor & - & {$[4,5,18,38,47,61]$} \\
\hline & Radiant Floor Conditioning & RFC & {$[62]$} \\
\hline \multirow[t]{15}{*}{ Radiant ceiling } & Ceiling embedded piping & - & {$[12,63]$} \\
\hline & Ceiling panels & - & {$[64,69]$} \\
\hline & Ceiling radiant cooling & - & {$[70,[71]$} \\
\hline & Ceiling Radiant Cooling Panels & CRCP & [72] \\
\hline & Ceiling radiant panels & - & {$[73,74]$} \\
\hline & Cold radiant ceiling panels & - & {$[28]$} \\
\hline & Cooled ceiling & $\mathrm{CC}$ & {$[20]$} \\
\hline & Cooling panels & - & {$[39,75]$} \\
\hline & Core Cooled Concrete Slab & CCCS & [31] \\
\hline & Hydronic Radiant Cooling & HRC & {$[22]$} \\
\hline & Hydronic radiant panels & - & {$[76,77]$} \\
\hline & Radiant ceiling & - & {$[78]$} \\
\hline & Radiant cooling/heating & - & [79] \\
\hline & Radiant hydronic slab & - & [23] \\
\hline & Radiant slab systems & - & {$[30,80]$} \\
\hline \multirow[t]{3}{*}{ Hollow core slab } & Active hollow core slabs & - & [17] \\
\hline & Hollow core slabs & - & {$[41,81,82]$} \\
\hline & Ventilated slab & - & {$[41,82,83]$} \\
\hline \multirow{11}{*}{$\begin{array}{l}\text { Concrete } \quad \text { Core } \\
\text { Slab* }\end{array}$} & Concrete core activation & $\mathrm{CCA}$ & [84-86] \\
\hline & Concrete core cooling/heating & - & {$[7,87]$} \\
\hline & Concrete Core Conditioning & $\mathrm{CCC}$ & $\begin{array}{l}{[11,15,34,37,40,62,88-} \\
96]\end{array}$ \\
\hline & Concrete radiant cooling slab & - & [97] \\
\hline & Concrete slab cooling & - & [98] \\
\hline & Floor-ceiling radiant panels & - & [99] \\
\hline & Pipe-embedded slabs & - & [9] \\
\hline & Slab heating/cooling & - & {$[14,100]$} \\
\hline & Thermally activated concrete slab & - & {$[101]$} \\
\hline & Thermo Active Building Systems & TABS & {$[8,10,31,37,85]$} \\
\hline & Thermo active components & - & [102] \\
\hline \multirow{5}{*}{$\begin{array}{l}\text { Pipe-embedded } \\
\text { envelopes }\end{array}$} & Active pipe-embedded building envelope & - & {$[103-106]$} \\
\hline & Thermal Barrier & TB & {$[42,107,108]$} \\
\hline & Thermo-active cooled wall & - & [109] \\
\hline & Vertical Thermo Active Buildings Systems & VTABS & [109] \\
\hline & Wall panels heating & - & [110] \\
\hline \multirow[t]{6}{*}{ TABS (general)* } & Hybrid Systems & - & [111] \\
\hline & Thermal active building system & TABS & {$[112]$} \\
\hline & Thermal slab & - & {$[113,114]$} \\
\hline & Thermally activated building components & - & {$[115-118]$} \\
\hline & Thermally activated building constructions & - & [119] \\
\hline & Thermally Activated Building Systems & TABS & $\begin{array}{l}{[13,15,16,23,24,29,33-} \\
36,40,52,89,90,93- \\
96,120-126]\end{array}$ \\
\hline
\end{tabular}




\section{TABS design}

The main standards around TABS design, sizing, installation and control are ISO 11855 [127], UNE 1264 [128] and UNE 15377 [129]. There are also guides as chapter 6 on ASHRAE Handbook Fundamentals [130] for radiant floors, REHVA Guidebook 7 [131] for radiant ceilings, floors and walls and REHVA Guidebook 20 [132] for concrete cores with ground coupled systems. For comfort analysis of TABS the standards are the same as for all HVAC systems, ISO 7730 [133], UNE-EN 15251 [134] and ASHRAE Standard 55 [135].

Moreover, different research has been done in the design methods of TABS. A concrete cores design method was developed to integrate the control strategy and heat gains boundaries in the design stage [33]. As heat gains are uncertain, a method was developed to calculate TABS capacity with upper and lower heat gains boundaries. It has also been pointed that cooling load for buildings equipped with TABS should be considered differently from conventional HVAC systems [40] due to the radiant nature of TABS. Design standards focus on heat flux and water conditions, on the other hand, comfort parameters such as maximum and minim surface temperature or maximum surface temperature difference are not taken into account. To solve this issue design charts were developed to link the main design parameters with surface temperatures and heat flux [38].

\subsection{Application range}

The application of TABS in current buildings depends on its capacity to supply enough heating and cooling demand without exceeding the surface temperature limits for comfort or condensation issues. Olesen [58] calculated the maximum cooling and heating capacity according to the limits of comfort conditions, the values are summarized in Table 2 . The maximum floor temperature is defined as the comfort limit from UNE 1264 [128] while the maximum wall temperature is the pain threshold for skin temperature in contact with the surface for a longer period of time and the maximum temperature for ceiling is the requirement to avoid radiant asymmetry. In contrast, the minimum temperatures consider the dew point and the condensation risk. Finally, heat transfer coefficients are obtained from previous research $[21,58]$.

Table 2: Heat exchange coefficient, surface temperatures comfort limits for different position and operation mode of TABS $[21,27,58]$

\begin{tabular}{|c|c|c|c|c|c|c|c|}
\cline { 3 - 8 } \multicolumn{2}{c|}{} & $\begin{array}{c}\text { Total heat exchange coefficient } \\
\left(\mathrm{W} / \mathrm{m}^{2} \cdot \mathrm{K}\right)\end{array}$ & \multicolumn{2}{c|}{$\begin{array}{c}\text { Surface temperature } \\
(\mathrm{o})\end{array}$} & \multicolumn{2}{c|}{$\begin{array}{c}\text { Capacity } \\
\left(\mathrm{W} / \mathrm{m}^{2}\right)\end{array}$} \\
\cline { 3 - 8 } \multicolumn{2}{|c|}{} & Heating & Cooling & Maximum & Minimum & Heating & Cooling \\
\hline \multirow{2}{*}{ Floor } & Perimeter & 11 & 7 & 35 & 20 & 165 & 42 \\
\cline { 2 - 8 } & Occupied zone & 11 & 7 & 29 & 20 & 99 & 42 \\
\hline \multicolumn{2}{|c|}{ Wall } & 8 & 8 & $\sim 40$ & 17 & 160 & 72 \\
\hline \multicolumn{2}{|c|}{ Ceiling } & 6 & 11 & $\sim 27$ & 17 & 42 & 99 \\
\hline
\end{tabular}

Different heating and cooling capacities are reported in the literature. For instance, in simulations under Montreal climate, hollow core slab supplied with outdoor air reached a peak cooling load of $40 \mathrm{~W} / \mathrm{m}^{2}$ and an average cooling load of $28 \mathrm{~W} / \mathrm{m}^{2}$ [81]. These are significant savings compared to the peak cooling load of $51 \mathrm{~W} / \mathrm{m}^{2}$ and the average cooling load of 44 $\mathrm{W} / \mathrm{m}^{2}$ of the mechanical cooling system in the same conditions. Night-time ventilated core slabs with outdoor air in the United Kingdom reached $50 \mathrm{~W} / \mathrm{m}^{2}$ of cooling load [83]. 
In the case of radiant floor cooling literature typically reports a cooling capacity of $50 \mathrm{~W} / \mathrm{m}^{2}$ but with solar radiation directly incident on the cooled surface cooling capacity can reach up to $100 \mathrm{~W} / \mathrm{m}^{2}[5,58,136]$. Maximum heating capacity for radiant floor was calculated to $100 \mathrm{~W} / \mathrm{m}^{2}$ at $20^{\circ} \mathrm{C}$ room temperature and $29{ }^{\circ} \mathrm{C}$ surface temperature [5], which are the comfort limits.

In contrast, radiant ceilings are limited by the $27^{\circ} \mathrm{C}$ maximum surface temperature which results in a maximum heating capacity of $42 \mathrm{~W} / \mathrm{m}^{2}$ [102] although $30-40 \mathrm{~W} / \mathrm{m}^{2}$ is recommended for design purposes [137]. Room test measurements and simulation showed a $50-65 \mathrm{~W} / \mathrm{m}^{2}$ maximum cooling capacity in gypsum board radiant ceiling with supply temperature of 15 ㅇ C [78]. In spaces directly illuminated with solar radiation an increase of $69 \%$ of cooling capacity was reported [40].

Finally concrete cores follow a similar trend. Lehmann et al. [90] calculated the maximum heat gains to maintain the temperature inside comfort ranges with concrete core cooling finding that the transitional periods are critical because of the high heat gains but short comfort range. In a well-insulated office building with night-time activated concrete core cooling the required cooling capacity was $25 \mathrm{~W} / \mathrm{m}^{2}$ [94]. A combined radiant floor and concrete core achieved $30 \mathrm{~W} / \mathrm{m}^{2}$ in an experimental study [112]. As reported in other types of TABS, concrete cores increased cooling capacity by $85 \%$ when direct solar radiation was incident on the surface [40].

The climate and cultural habits also influence in the application of TABS. In Korea, where the use of radiant floor heating is common, radiant floor can also be used for cooling if condensation issues in the hot humid summer and comfort problems due to floor sitting habits [48] are overcome. However, auxiliary cooling and ventilation systems were recommended [51]. In the similar climate of Hong-Kong, cooling radiant ceiling panels showed potential for significant energy savings if coupled with dehumidifying ventilation systems. In contrast, in the Nebraska continental climate TABS coupled with a ground system and with assisted ventilation showed great potential in terms of primary energy and comfort [10]. In Poland, another continental climate, Thermal Barriers coupled with different temperature ground sources showed significant savings [42] both in heating and cooling seasons. The comparison of the application of concrete core cooling or suspended ceiling panels in northern and southern Europe showed great potential in southern Europe and the Mediterranean area [11]. However, on northern Europe cooling with night ventilation and mechanical night ventilation might be more energy efficient than water based TABS. Finally, despite having demonstrated peak load shaving and peak load shifting potential some authors opined [31] to not recommend installation of TABS on exposed roofs for tropical climates as it reduces its cooling capacity.

\subsection{TABS distribution topology}

TABS control and performance are also influenced by the topology of the distribution system. A building with zones with different heat gains may need different supply temperatures to maintain comfort. It is possible that different control strategies have to be used in each zone, for example needing different heating curves [15], and even two zones could simultaneously demand heating and cooling. 
Zone configuration defines the number of different areas that will be supplied. Each zone requires its own supply curve so it is recommended to group rooms with similar heat gains [121].

Single zones topology, shown in Figure 6 right, is the simplest to implement, as it has a single heating curve and only requires a two pipe configuration, one for supply and another for return. However its control is demanding because only a single supply temperature is available independently of the heat gains of the rooms.

In contrast multiple zones can consider different supply, circulation and return topologies:

- In the supply side separated supply pipes allow for simultaneous supply of cooling and heating to different zones, case shown in Figure 6 left.

- Circulation pipes allow mixing the outlet flow with the supply flow, thus allowing for different supply temperature. Each zone having a separated circulation pipe gives more flexibility in the supply temperature. In contrast, common circulation pipe can have undesired cooling demands if outside temperature is not within the range where heating curves overlap [36], as the common return water might be too hot for supplying the zone with less heat gains as shown in Figure 7.

- Separated pipes on the return side might avoid mixing the return flows from simultaneous cooling and heating in different zones, thus improving the efficiency of chillers and boilers it the return temperatures were significantly different, case shown in Figure 6 left.

Renggli et al. [95] showed a case with two supply pipes where heating demand is $28 \%$ and the cooling demand $30 \%$ less with the separate circulation topology compared to common circulation pipe. However, Wit and Wisse [121] commented that separated circulation might not be necessary if heat loads are similar in all zones. Furthermore, they affirmed that two supply pipes and two return pipes are unnecessary, as simultaneously delivery of heat and cold occur in periods where heating and cooling are supplied at similar temperatures.
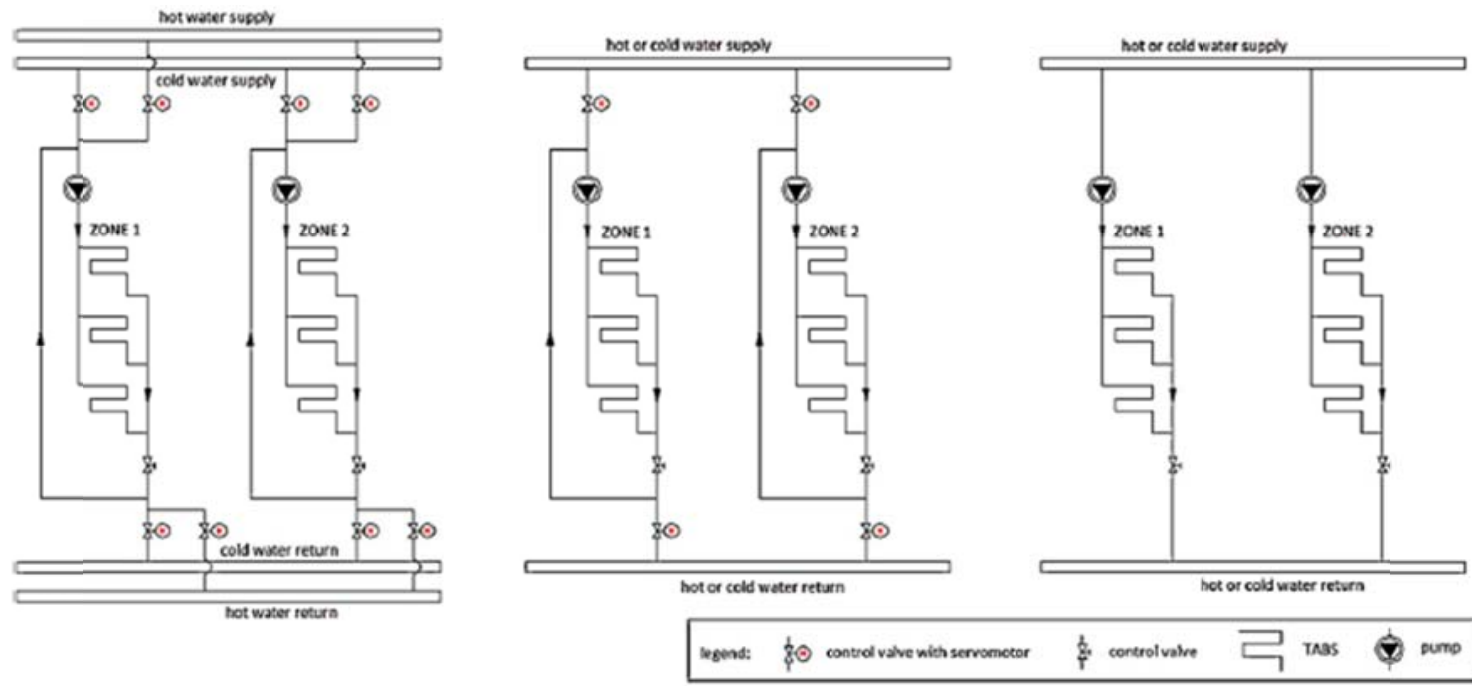

Figure 6: Separated zones with four pipe topology and separated circulation (left), separated zones with two pipes and separated circulation (middle), single zone (or no zone division) with two pipes topology and no circulation (right) [121] 


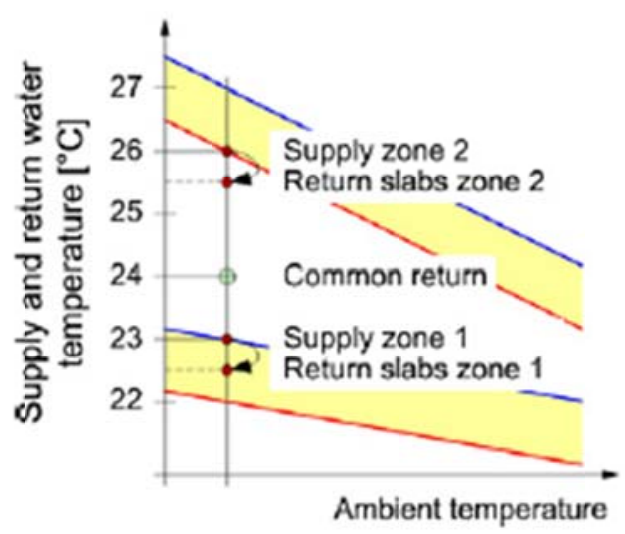

Figure 7: Example of separate zones with common return pipe topology where heating curves do not overlap, overheating will occur on zone 1[36]

\subsection{Parametric studies}

Parametric studies have been carried to find the parameters that most influence to TABS performance. This is a crucial step in the improvement of TABS in the design step.

Antonopoulos et al. [12] showed that for ceiling with embedded piping, the parameters that affect more the slab performance are pipe spacing, pipe depth, water inlet temperature, indoor temperature and indoor heat load. For ceiling cooling panels at $20 \mathrm{~cm}$ spacing between pipes, the under-surface of the slab has temperature differences that are not found at $10 \mathrm{~cm}$ spacing [39], this is more pronounced at low fluid temperature. In pipe-embedded envelopes, a reduction of pipe spacing of $50 \mathrm{~mm}$ results in a reduction of heat transfer by $2.3 \mathrm{~W} / \mathrm{m}^{2}$ on the internal surface [103]. In the same study it was also found that that the internal surface heat transfer may be reduced by $2.6 \mathrm{~W} / \mathrm{m}^{2}$ when supply temperature is reduced $1 \circ \mathrm{o}$.

The width of the slab and the position of the pipes influence the volume of TABS that is activated. Babiak et al. [101] proposed an effective thickness of $15 \mathrm{~cm}$ to fully activate the slab. The position of the pipes depends on the operation mode and the thermal resistance of the surface, however, it was recommended to place them at the mean slab level at $7.5-10 \mathrm{~cm}$ from ceiling surface or less. On Thermal Barriers (TB) maintaining a surface at a constant temperature the pipes should be placed near the external surface of the concrete layer [42], near the external insulation. If the TB is positioned nearer the indoor surface its efficiency is reduced, although the ineffective area can be reduced adding insulation on the indoor surface.

Hauser et al. [98] compared comfort conditions achieved in rooms with various-weighted walls conditioned with ceiling panels. Heat extracted averages $60 \mathrm{kWh} / \mathrm{m}^{2}$ annually in all cases. Heavy weight walls have slightly fewer hours outside comfort range compared to light-weight walls. Similarly Kolarik et al. [37] found that walls with higher thermal mass have slightly more energy consumption while lower thermal mass walls have higher temperature drift and exceed comfort range more often. Low thermal mass on TABS causes the building to not benefit from high thermal resistance [33]. Low thermal resistance increases the variation of mean operative temperature, however, the minimum operative temperature variation is about $1.5{ }^{\circ} \mathrm{C}$ and it cannot be further reduced even increasing both thermal mass and thermal resistance. It is observed that radiant wall panels are more sensitive to insulation than conventional systems [110], better insulation improves TABS savings even further. 


\section{TABS simulation}

TABS design and performance studies involve complex dynamic heat transfer calculations. Simulation models have to take into account convection from the fluid to the slab, conduction through the slab and both convection and radiation on the surfaces. Radiant panels on ceilings and floors are usually modelled to exchange heat only to the surface exposed to the room, while the other surface is often considered as adiabatic. Contrary, TABS embedded on the structure, concrete core slabs or wall embedded pipes, usually require to be modelled to exchange heat in both surfaces. Also TABS have multi-layered structures and significant thermal mass, which adds complexity to simulation. Dynamic simulation is usually necessary to study TABS performance.

Within this context, heat flow to rooms is the main parameter to be obtained by simulation. However, to study comfort conditions and to assess condensation issues, the surfaces average temperature or the temperature distribution might be required. Detailed temperature maps through the slabs might be required in parametric studies.

Only numerical methods as finite element method (FEM) and finite difference method (FDM) describe the heat transfer and heat storage capacities of TABS accurately. Unfortunately, numerical methods are time consuming and complex to couple with building simulation environments. Thus, lot of research have been conducted to develop simplified models for TABS which reduce computational effort and are accurate enough for the expected application range. These simplified models are usually validated with numerical methods and/or calibrated with field measurements.

A summary of the models for TABS simulation is presented in Table 1.

\subsection{Numerical models (FEM, FDM, FVM)}

Numerical models solve the differential equations of heat and mass transfer by limiting a set of finite elements, grid-points, in the calculation domain. The method establishes a set of algebraic equations to the unknown values of the dependant variable on these finite elements and then establishes an algorithm to solve these equations [138].

Zmeureanu and Fazio [81] developed a model for simulating a building with hollow core concrete ventilated slabs. Heat balance is applied to indoor air and radiation is calculated with Modified Thermal Balance (MTB) method. Solar radiation is distributed uniformly through surfaces. Walls are considered one-dimensional and modelled with three nodes. The hollow core slab is modelled in 2D finite difference (FDM), considering the direction of air flow and perpendicular to the surfaces. The bottom surface of the slab is considered adiabatic. For simplification air temperature variation along the ducts is solved analytically.

In a similar application, Fort [139] described a model for hypocaust under-floor heating 2D FDM model, which is coupled with TRNSYS. The model is designed for floor heating but it is also applicable to wall panels and cooling ceiling panels in which either air or water can be used. The model consists of a simplification of the slab where circular ducts are simplified to square pipes for an easier distribution of nodes. In case the ducts are pipes its width is not considered. Its input parameters are the fluid supply temperature, the flow rate and the thermal behaviour conditions of surrounding rooms and the output parameters of the model 
are outlet temperature of the fluid, heat flux on the surfaces, surface temperatures and energy stored in the panel. The model requires a shorter time step than the usual TRNSYS time step.

FDM was also used for roof slabs, in that case Antonopoulos and Democritou developed a 2D FDM in a periodic steady state [39]. No temperature variation is considered in the fluid, and room temperature is used as a boundary condition to obtain the heat flow on both surfaces of the slab, the temperature distribution inside the slab and the heat flow absorbed by the fluid at each hour of the day while outdoor boundary conditions vary periodically. Later, Antonopoulos and Tzivanidis [63] developed a FDM 3D transient model for a roof slab where the slab around one pipe is modelled with a fine mesh as shown in Figure 8. It is assumed that the pipe wall thermal resistance is negligible and that there is no heat transfer between pipes, so walls between control volumes are adiabatic. Total heat flux is calculated with the total number of pipes embedded in the roof. This model calculates indoor temperature, temperature distribution in the slab and fluid temperature variation along the pipe. Comparing against the previous models [39,75], discrepancies reach up to $35 \%$ in temperature distribution, $15 \%$ in fluid temperature distribution and $7 \%$ in room temperature [63]. A correlation to calculate ceiling embedded-piping cooling power was developed with the obtained results.

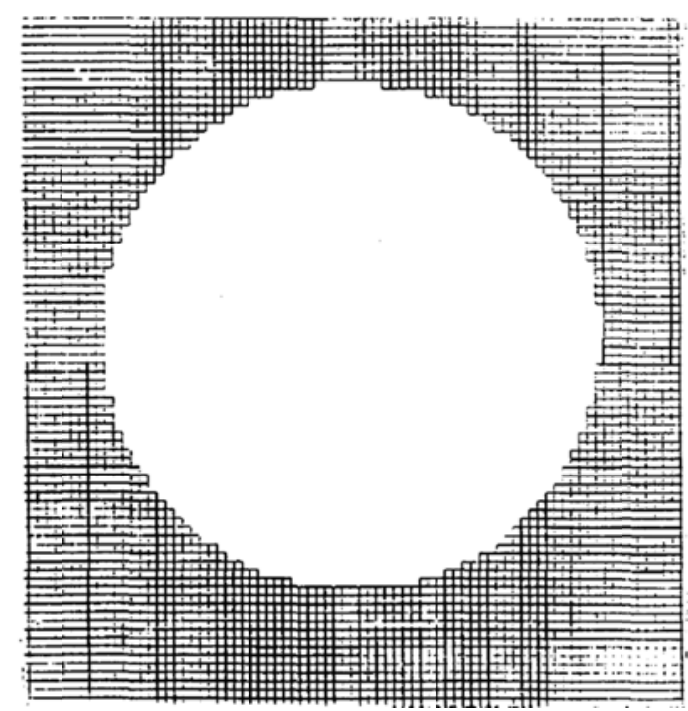

Figure 8: $x$-y plane grid used by Antonopoulos and Tzivanidis [63] for discretizing pipes surroundings

Most of the FDM have dense grids thus long computational times, focusing on this point, Holopainen et al. [44] studied floor heating with uneven gridding to reduce the number of nodes. The cases of uniform concrete floor slab and multi-layered floor slab are chosen to use $2 \mathrm{D}$ analytical solutions in steady state as reference. Uneven distribution of nodes is done with geometric series for each layer as shown in Figure 9. With space incremental optimal values the uneven grid was compared to an even grid with the same number of nodes and to an even grid with the same accuracy. Results show that uneven grid can reduce the number of nodes and the computational time. The uneven grid has better results with uniform concrete floor slab than in a multi-layered case because nodes can be placed more freely than in the multilayered floor slab. 


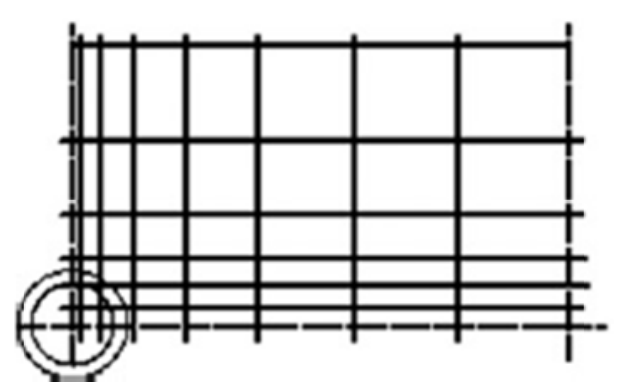

Figure 9: Uneven TABS discretization [44]

Numerical models have also been applied to vertical TABS. Krzaczek and Kowalczuk [42] presented a 3D finite elements model (FEM) to simulate a prefabricated wall with Thermal Barriers. The control volumes are blocks of horizontal $U$ pipe embedded in the middle of the wall, considering upper and bottom surfaces, those normal to active surface, as adiabatic. The model uses the FEM code of ABAQUS software with a complete discretization of the $U$ pipe, which is shown in Figure 10.

Despite most of the models are applied to time domain Zhu et al. presented a 2D Frequency Domain Finite Differences (FDFD) model [104] for active pipe embedded envelopes. Nodes are modelled with four resistances and one capacitance. The equations obtained are solved with Generalized Minimum Residual method (GMRES). The performance of the structure was simulated under different combinations of the perturbations of temperature of external surface; temperature of internal surface; and circular temperature of the fluid in the pipe. Computational Fluid Dynamics (CFD) was used for comparison. The developed FDFD has an error of $7 \%$ in amplitude but reduces computational time from $3 \mathrm{~h}$ to $5 \mathrm{~min}$ in the tested conditions.

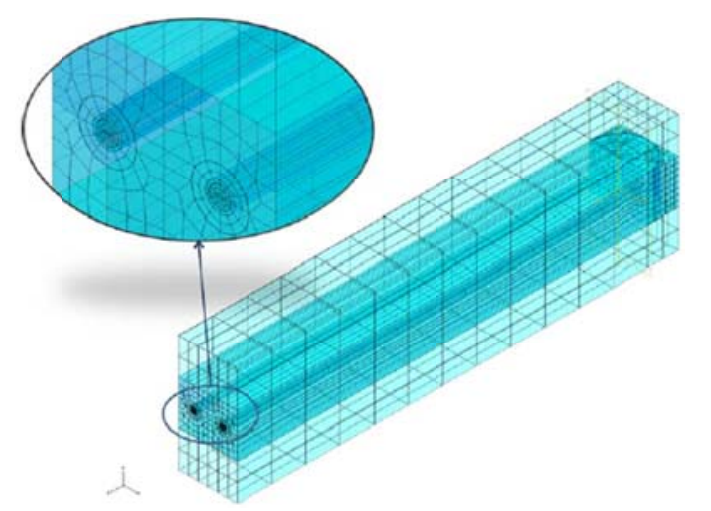

Figure 10: FE discretization of a TB [42]

\subsection{Analytical models}

Analytical models are based on exact solutions of the differential equations of heat transfer. Due to the complexity of the equations these models are limited to specific cases and require adequate assumptions to describe accurately enough the heat transfer process. This factor limits analytical models to $1 \mathrm{D}$ or simple 2D and to steady-state conditions. However, once developed, an analytical model requires low computational effort thus it is very easy to implement to a building simulation environment or be used for control purposes. 
An initial cooling panel analytical model was presented by Antonopoulos [75]. He solved a steady state 1D analytical model assuming the panel as a fin with heat fllow between two pipes, convection one side and adiabatic on the other, the geometry of the panel is shown in Figure 11. The fin equations are combined through panel efficiency factor to use an analytic solution of a fluid along a pipe. The model calculates de heat absorbed by the slab according to fluid inlet temperature and room temperature. Heat exchange to the room is only considered with a heat transfer coefficient. Jeong and Mumma [71] also used the temperature distribution derived from the energy balance of a fin to improve a 2D steady analytic model for ceiling panels. The improvements were focused on estimation of the mixed convection effect on the cooling capacity, finding that mixed convection significantly increase ceiling panels cooling capacity.

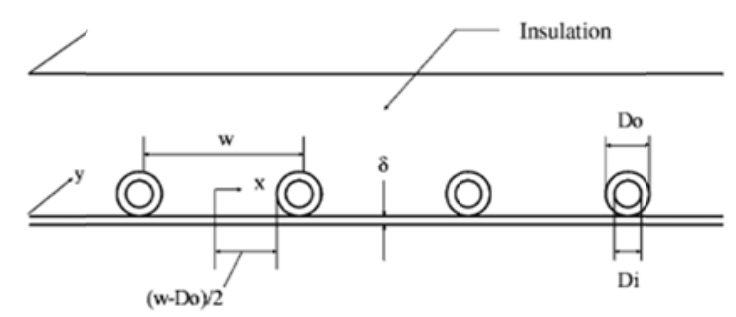

Figure 11: Jeong and Mumma [71] ceiling panels geometry

A more elaborated model was developed by Koschenz and Lehmann [140]. A TABS with a parallel heating/cooling pipe system and a uniform slab was solved in an exact steady state 2D solution. The slab is considered to have convection on the upper surface and to be insulated on the bottom (adiabatic). This model was further developed to a $2 \mathrm{D}$ transient analytical model by Larsen et al. [141] who used separation of variables, superposition method and orthogonal expansion techniques to develop the dynamic solution. The resulting solution is in the form of infinite series in space variable with exponential time dependency. The method applied can be used to develop a model for TABS with convection on both surfaces, which is a more general case. Li et al. [56,57] also used Koschenz and Lehman [140] solution and developed a simplified method for calculating the mean temperature and minimum temperature of multi-layered radiant floor. The new model does not consider water temperature variation along the pipes, assumes symmetry around pipes and no heat flow on the bottom surface. It uses the Equivalent Thermal Resistance Method (ETRM) to transform the multi-layered slab in a homogeneous slab of fictitious thickness where the analytical 2D solution for homogeneous slabs [140] can be applied. The validation with experimental results showed an error of less than 0.4 ㅇ․

In a different approach, Simoes and Tadeu [142] used Green equations to formulate the 2D heat flow across a multi-layered slab with heat sources. The thermal response was first studied in the frequency domain and then traduced to time domain by Fourier transform. The effect of convection on the surfaces is considered and shows great effect on the performance. The results showed that the formulation was promising for simulating multi-layered constructions.

Yet Sarbu and Sebarchievici [99] proposed another different analytic model for thermal emission of radiant floors. The model is based on virtual tube method [143] and allows calculating the mean heat flow and the temperature at each point of the surface, considering 
there is only heat flow in the 2D plane perpendicular to the pipes. The model does not take into account the dynamics of the system but was validated with measured values showing reasonable agreement.

\subsection{Semi-analytical models}

While analytic models have accurate results they are limited to geometries and conditions where solutions can be found with reasonable assumptions. To overcome the limitations of analytical models some authors proposed correlation between different analytic solutions to develop more complex solutions such as TABS heat transfer. Such models are described as semi-analytic. A first model for TABS simulation was a semi-analytic model developed by Zhang and Pate [68] for heating with ceiling panels, it is a two dimensional steady state model.

Usually TABS radiant floors models consider ground temperature as uniform. To compensate this, Chunagchid and Krarti [43] developed a semi-analytic 2D model in periodic steady for concrete slab floors. The model describes the temperature field of the slab and the ground and the heat gains or losses to the soil. It was validated with measurement and it was found suitable for TABS design as it considers many TABS variables.

Laouadi [46] presented a 2D semi-analytical model oriented to be implemented in simulations programs which were currently using $1 \mathrm{D}$ models for radiant heating cooling systems. On one set, the model uses analytical solution of a 2D slab with heat sources. Separately, it calculates the heat transfer inside the tubing. The semi-analytical model was found to have excellent matching to a numerical model in uniform physical properties case and it only has up to $11 \%$ error in no-uniform physical properties case.

In contrast, Jin et al. [53] presented a method for estimating the surface temperature of multilayered radiant floor systems. The floor is divided into two layers, one containing the pipes and the other containing all other layers of different materials. Using a numerical model, authors developed a correlation to calculate the conductivity of the layer containing the pipes as a function of the characteristic parameters of the radiant floor. The model assumes that temperature at each layer surface is uniform and that the bottom surface is adiabatic, heat flux is 1D from the pipes to the floor. The model was compared to experimental results of Song and Buttock [45] finding a difference with calculated results of less than 2.5K. The model was also compared against other numerical models [44] finding the same surface temperature.

The effect of assumptions on a semi-analytic model has been studied by Tye-Gingras and Gosselin [76]. They considered panels with negligible mass so that steady state assumption could be applied to a 2D semi-analytic model. The results are that assumptions led to negligible errors in a large range of geometries. Furthermore, the semi-analytic model is faster than a numerical model and more flexible than an analytical model [71]. The model was later applied for panels optimization coupled to a room CFD model showing its capacity for TABS design calculation [77].

\subsection{Resistor Capacitor models (RC)}

$\mathrm{RC}$ or lumped models parameter models simplify the description of heat transfer in a space by describing heat transfer between selected nodes as an equivalent electric circuit. Resistances 
(R) represent the thermal time constants and the capacitances (C) represent the heat capacity of the element.

Ren and Wright [41] developed a lumped model (resistor capacitor model) for hollow core concrete slab and associated zone. The walls are represented as a capacitance and two resistances, each representing the resistance to indoor and outdoor disturbance. For the ventilated slab it is assumed that there is no heat transfer between upper and lower surface and that the temperature was uniform in the direction of air-flow. Then the slab is represented as shown in Figure 12 with two walls with a common node that is the mean temperature of the air. The model is compared to a set of measured values giving good accuracy.

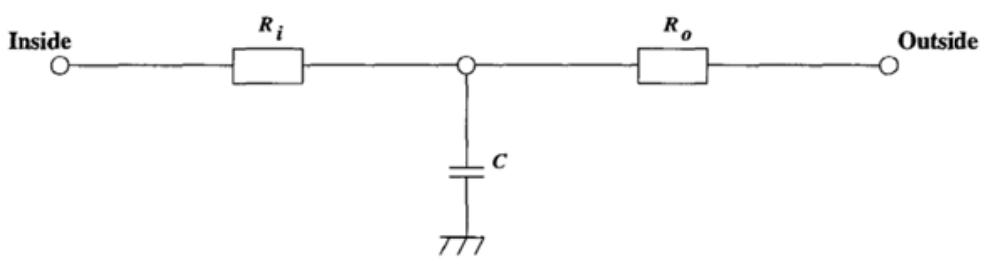

Figure 12: Simplified lumped model representing two walls with the mean air temperature in the ducts as a common node [41]

Using a similar concept and bringing it and step further Koschenz and Dorer [88] proposed a simplified 2D transient model for slabs. The model is coupled to the multi-zone building model of TRNSYS. TABS are modelled as two walls separated with a dummy zone that represents the water system. Heat transfer coefficients in this area are applied as three resistances as shown in Figure 13 left. For transient cases, thermal resistances are time-depended.
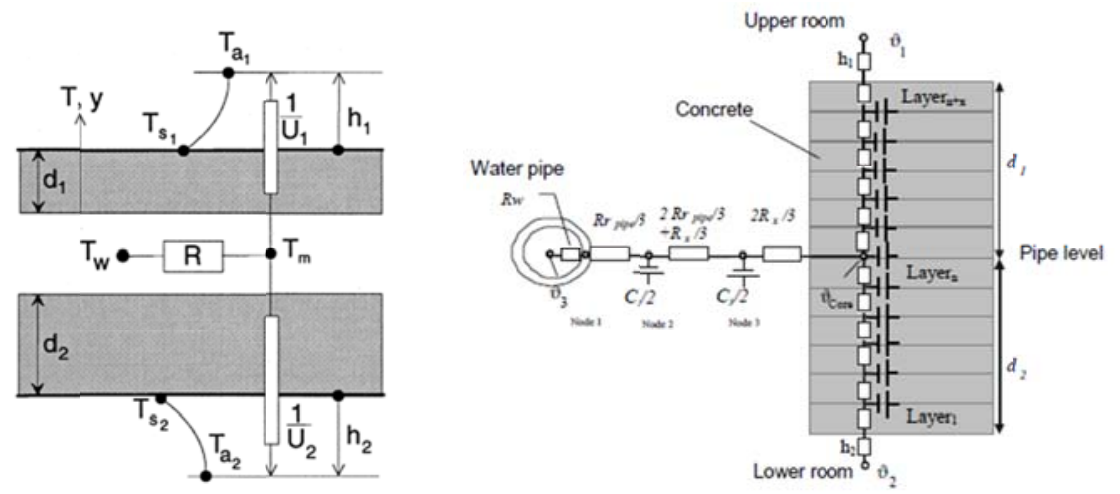

Figure 13: 1D resistance modelled by Koschenz and Dorer [88] (left) and improved model by Weber (right)[115]

Using the same concept of the core layer temperature Liu et al. [87] define a simplified startype RC-network model for simulating concrete core cooling slabs. Here, heat transfer through the slab is defined as heat transfer from chilled fluid to the core layer and heat transfer from core layer to slab surfaces. In the star RC-network the central node is treated as the core layer. Compared to a FEM model the RC-network shows good accuracy in both steady and unsteady conditions. Authors study the application range of the model finding that temperature fluctuation cycle should be above $2.51 \mathrm{~h}$.

Also based on Koschenz and Dorer concept [88], Tian et al. [97] developed a simplified 2D model for dynamic simulation of concrete radiant cooling and validated it with experimental 
measurements. The model was developed based on the reaction coefficient method, simplifying the Koschenz and Dorer model to the heat transfer between four nodes in star configuration. The developed model is also compared to other simplified models $[44,87]$ and to a full scale laboratory model. Bland-Altman is used to analyse the consistency of experimental and simulated results. In steady conditions the developed model had an error lower than $1.5 \%$ compared to experimental results and an error lower than $2 \%$ compared to other simplified models. In un-steady conditions the error was lower than $7 \%$ compared to experimental measurements.

The network proposed by Koschenz and Dorer [88] was improved by Weber [115] using w-RCTransform methodology and applying multipoint RC-networks for TABS. The improve model represents links between points with quadrupols and uses the transformation from triangle to star net-works leading to an optimized configuration [118], the resulting configuration is shown in Figure 13 (right). Calculation in frequency domain shows that the RC model matches the FDM in the range of application. In time domain, the RC model matches accurately to measured temperatures in a concrete slab of a building [117].

The w-RC-Transform method wass also used by Schmidt and Jóhannesson [111] who presented a method for modelling hybrid building constructions with few nodes. The method consists in studying the thermal admittance and capacitance of the TABS system in the frequency domain with the analytic solution of Finite Difference Method. The obtained admittance values and capacitance values are used to optimize an RC-network with the method of w-RC-Transform. The RC network can then be used coupled with simulation environments to study the whole building performance. On a later study Schmidt and Jóhannesson [119] described the method to apply this simplified RC model to macro-elements modelling (MEM), where the structure is divided to limited number of mass nodes each with its own optimized RC-network. This method is accurate and requires fewer nodes than numerical models.

In less complex approach, Zhang et al. [55] developed a simplified calculation for key parameters of radiant floor. Heating/cooling capacity, surface temperature distribution and lowest temperature are calculated considering heat transfer in the slab as heat resistance in series based on the principle of superposition of heat resistance. Assumptions are symmetry between pipes, no heat transfer in pipes direction, and adiabatic bottom surface. Compared to previous studies $[59,88]$ the simplified calculation has only $8-10 \%$ of heat flux error.

Following their own previous research [104], Zhu et al. [105] used the FDFD model to verify a simplified RC model. The walls are modelled as 5 resistances and 2 capacitances as can be observed in Figure 14 and it is referenced as 5R2C model. The parameters of this model are estimated using a genetic algorithm. However, the 5R2C model alone cannot predict temperature variation along the pipe. To solve this problem authors coupled a Number of Transfer Units (NTU) model to the 5R2C model, thus creating a semi-dynamic model [106]. Compared to CFD the simplified model has a deviation up to $5 \%$ on high frequency periods, although it was influenced on physical properties. 


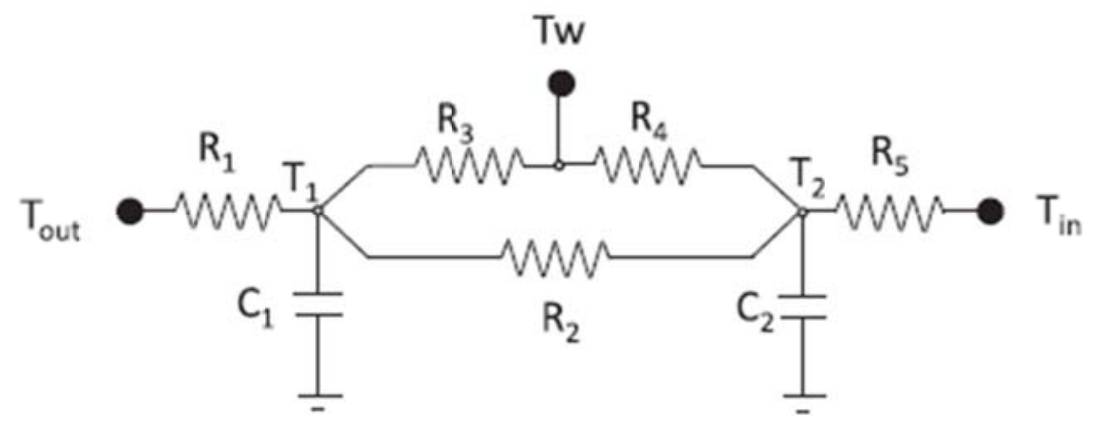

Figure 14: 5R2C model used by Zhu et al. in $[105,106]$

\subsection{Transfer function models}

Mathematical methods based on transforms and operators are widespread methods for solving non-steady heat transfer problems. Transfer Function Method is considered an accurate method for calculating time-variable heat loads that establish a relation between an input and output. In the current case, the transfer function of TABS will establish a relation between the outdoor conditions, the input, and the internal heat gains, the output.

Chae and Strand [82] developed a model for ventilated slabs integrated in EnergyPlus. It considers the slab as a heat exchanger with a stationary fluid on the room side and a cooling coil on the other. The room side of the heat exchanger connects with the surface heat balance. The cooling coils are represented with modified conduction transfer functions that accept internal heat sources and sinks [144] which are already implemented in EnergyPlus. The heat exchanger is modelled using the $\varepsilon$-NTU model. In the ceiling slab presented in the paper no heat flux is considered to the upper storey. The model is verified against a numerical model [81].

\subsection{Identification models}

Identification models use statistical methods to obtain a model from a set of data. Logically, these models require to have previous measurement of the involved building, however, once developed these models are very easy to apply. Identification models are frequently related to Model Predictive Control (MPC).

The two main streams in identification models were compared by Ferkl and Šyroky [70] on a building equipped with the "Critall" ceiling radiant cooling system. On one side AutoRegressive Moving Average model with eXogenus inputs (ARMAX) shows better results in systems with high signal noise. On the other, subspace state space identification is faster to implement and to tune.

In a study on identification methods applied concrete core activation modelling Sourbron et al. [86] tested the impact of the model structure and the identification data set on Model Predictive Control performance. The findings were that second-order models achieve the same performance than fourth order models and the inclusion solar or internal gains improve control performance.

The application and improvement of identification models was carried by Privara et al. [74]. The authors proposed and improved MPC Relevant Identification (MRI) coupled to Partial Least 
Squares (PLS). This was compared to standard one-step ahead minimization and to a conventional MRI into an application to a TRNSYS building model and to an actual office building [90]. Both MRI have similar results and significantly improve the one-step ahead minimization.

\subsection{Simulation software}

Modelling is useful for parametric studies of TABS. However, the main motivation of TABS modelling is to obtain reliable tools that can be integrated in building simulation environments. Free building simulation software area available such as ESP-r [145], DOE2 [146] or its evolution, the eQuest [147] which adds a radiant module that the first version lacked. Some authors developed their own simulation programs like ACCURACY [69], for simulating rooms with radiant ceilings, and DIGITHON [78], which simulates rooms equipped with radiant systems. Also some companies developed building simulation software like Clim2000 [148], ESP-r/HOT3000 [149]. Building simulation environments like EnergyPlus [150], IDA-ICE [151] and IES-VE [152] or transient simulation software like TRNSYS [153] integrate modules for simulation of different types of TABS. Some research have been done to compare the different software capabilities [154] finding significant magnitude differences in the same conditions [126] which are related to the different detail in the models. 
Table 3: Summary of TABS simulation models

\begin{tabular}{|c|c|c|c|c|}
\hline Reference & System & Model type & Study type & Main findings \\
\hline $\begin{array}{l}\text { Zmeureanu } \\
\text { and Fazio [81] }\end{array}$ & $\begin{array}{l}\text { Hollow core } \\
\text { slab }\end{array}$ & $\begin{array}{l}\text { 2D Transient } \\
\text { FDM }\end{array}$ & $\begin{array}{l}\text { Energy and } \\
\text { thermal } \\
\text { comfort } \\
\text { analysis }\end{array}$ & $\begin{array}{l}\text { Hollow core slabs provide comfort during } \\
\text { occupancy and reduce cooling loads. Ventilation } \\
\text { rate should be increased during night to ensure } \\
\text { reduction of cooling loads }\end{array}$ \\
\hline Fort [139] & $\begin{array}{l}\text { Hypocaust } \\
\text { and } \\
\text { murocaust }\end{array}$ & $\begin{array}{l}\text { 2D Transient } \\
\text { FDM }\end{array}$ & $\begin{array}{l}\text { Model } \\
\text { development } \\
\text { and } \\
\text { integration to } \\
\text { TRNSYS }\end{array}$ & $\begin{array}{l}\text { The model can be coupled to TRNSYS building } \\
\text { simulation but requires shorter time step }\end{array}$ \\
\hline $\begin{array}{l}\text { Antonopoulos } \\
\text { and } \\
\text { Democritou } \\
\text { [39] }\end{array}$ & $\begin{array}{l}\text { Ceiling } \\
\text { cooling } \\
\text { panels }\end{array}$ & $\begin{array}{l}\text { 2D periodic } \\
\text { steady state } \\
\text { FDM }\end{array}$ & $\begin{array}{l}\text { Parametric } \\
\text { study }\end{array}$ & $\begin{array}{l}\text { Pipe spacing is the parameter most influencing } \\
\text { on the surface temperature field, its influence is } \\
\text { more significant at low fluid temperature }\end{array}$ \\
\hline $\begin{array}{l}\text { Antonopoulos } \\
\text { et al. [63] }\end{array}$ & $\begin{array}{l}\text { Ceiling } \\
\text { embedded } \\
\text { panels }\end{array}$ & $\begin{array}{l}\text { 3D Transient } \\
\text { FDM }\end{array}$ & $\begin{array}{l}\text { Heat transfer } \\
\text { model }\end{array}$ & $\begin{array}{l}\text { Temperature discrepancies up to } 35 \% \text { in the slab, } \\
15 \% \text { in the fluid and } 7 \% \text { in the room compared to } \\
1 D \text { steady and } 2 \mathrm{D} \text { transient models }\end{array}$ \\
\hline $\begin{array}{l}\text { Holopainen et } \\
\text { al. [44] }\end{array}$ & Radiant floor & $\begin{array}{l}\text { 2D Transient } \\
\text { FDM }\end{array}$ & $\begin{array}{l}\text { Model } \\
\text { development }\end{array}$ & $\begin{array}{l}\text { Uneven discretization can reduce by } 95 \% \text { the } \\
\text { number of nodes on homogeneous slabs and } \\
55 \% \text { in multi-layered slabs thus significantly } \\
\text { reducing simulation time }\end{array}$ \\
\hline $\begin{array}{l}\text { Krzaczek and } \\
\text { Kowalczuk } \\
{[42]}\end{array}$ & $\begin{array}{l}\text { Thermal } \\
\text { barrier }\end{array}$ & $\begin{array}{l}\text { 3D transient } \\
\text { FEM }\end{array}$ & $\begin{array}{l}\text { Parametric } \\
\text { study }\end{array}$ & $\begin{array}{l}\text { TB stability is not affected by active layer } \\
\text { position but for wall composition. TB maintained } \\
\text { at } 17 \text { - } \mathrm{C} \text { reduces indoor heating demand }\end{array}$ \\
\hline Xu et al. [104] & $\begin{array}{l}\text { Pipe- } \\
\text { embedded } \\
\text { envelopes }\end{array}$ & $\begin{array}{l}\text { Finite } \\
\text { Difference } \\
\text { Frequency } \\
\text { Domain } \\
+ \text { CFD } \\
\end{array}$ & $\begin{array}{l}\text { Model } \\
\text { validation } \\
\text { And heat } \\
\text { transfer } \\
\text { analysis } \\
\end{array}$ & $\begin{array}{l}\text { The developed FDFD model matches accurately } \\
\text { the results of the CFD model. The pipe- } \\
\text { embedded envelops actively intercepts heat and } \\
\text { coolth }\end{array}$ \\
\hline $\begin{array}{l}\text { Antonopoulos } \\
{[75]}\end{array}$ & $\begin{array}{l}\text { Cooling } \\
\text { panels }\end{array}$ & $\begin{array}{l}\text { 1D Steady } \\
\text { Analytical }\end{array}$ & $\begin{array}{l}\text { Model } \\
\text { development } \\
\text { and } \\
\text { verification }\end{array}$ & $\begin{array}{l}\text { The analytical solutions in the normal and } \\
\text { parallel direction of the pipes agree with the } \\
\text { results of a 2D model with much easier } \\
\text { implementation }\end{array}$ \\
\hline $\begin{array}{l}\text { Jeong and } \\
\text { Mumma [71] }\end{array}$ & $\begin{array}{l}\text { Ceiling } \\
\text { radiant } \\
\text { cooling } \\
\text { panels }\end{array}$ & $\begin{array}{l}\text { 2D steady } \\
\text { analytical }\end{array}$ & $\begin{array}{l}\text { Model } \\
\text { development, } \\
\text { cooling } \\
\text { capacity } \\
\text { analysis } \\
\end{array}$ & $\begin{array}{l}\text { Mixed convection can improve significantly the } \\
\text { cooling capacity of ceiling panels }\end{array}$ \\
\hline $\begin{array}{l}\text { Koschenz and } \\
\text { Lehmann } \\
{[140]}\end{array}$ & TABS & $\begin{array}{l}\text { 2D Steady } \\
\text { Analytical }\end{array}$ & $\begin{array}{l}\text { Model } \\
\text { development }\end{array}$ & $\begin{array}{l}\text { Exact model for uniform slabs and parallel pipes } \\
\text { distribution }\end{array}$ \\
\hline $\begin{array}{l}\text { Larsen et al. } \\
{[141]}\end{array}$ & $\begin{array}{l}\text { Embedded } \\
\text { array of } \\
\text { pipes }\end{array}$ & $\begin{array}{l}\text { 2D Transient } \\
\text { Analytical }\end{array}$ & $\begin{array}{l}\text { Model } \\
\text { development }\end{array}$ & $\begin{array}{l}\text { Application of variables separation and } \\
\text { orthogonal expansion allows to develop a } \\
\text { transient solution from a previous } 2 \mathrm{D} \text { steady } \\
\text { model [140] and apply it to a case with } \\
\text { convection in both surfaces }\end{array}$ \\
\hline $\begin{array}{l}\text { Li et al. } \\
{[56,57]}\end{array}$ & Radiant floor & $\begin{array}{l}\text { Steady } \\
\text { Analytical }\end{array}$ & $\begin{array}{l}\text { Model } \\
\text { development } \\
\text { and } \\
\text { validation }\end{array}$ & $\begin{array}{l}\text { Model determines max, min and mean surface } \\
\text { temperature with an error about } 0.3^{\circ} \mathrm{C} \text { compared } \\
\text { to experimental values }\end{array}$ \\
\hline $\begin{array}{l}\text { Simoes and } \\
\text { Tadeu [142] }\end{array}$ & $\begin{array}{l}\text { Multi layered } \\
\text { slabs with } \\
\text { heat sources }\end{array}$ & $\begin{array}{l}\text { 2D Transient } \\
\text { Analytical }\end{array}$ & $\begin{array}{l}\text { Model } \\
\text { development }\end{array}$ & $\begin{array}{l}\text { The application of green equations has potential } \\
\text { for studying transient heat transfer on multi- } \\
\text { layered slabs }\end{array}$ \\
\hline $\begin{array}{l}\text { Sarbu and } \\
\text { Sebarchievici } \\
\text { [99] }\end{array}$ & $\begin{array}{l}\text { Floor heating } \\
\text { panel }\end{array}$ & $\begin{array}{l}\text { Steady } \\
\text { Analytical }\end{array}$ & $\begin{array}{l}\text { Model } \\
\text { development, } \\
\text { validation } \\
\text { and } \\
\text { comparative } \\
\text { energy } \\
\text { performance } \\
\text { study }\end{array}$ & $\begin{array}{l}\text { Model determines the temperature at any point } \\
\text { on the surface and the mean heat flux and give } \\
\text { coherent results with experimental } \\
\text { measurements }\end{array}$ \\
\hline
\end{tabular}




\begin{tabular}{|c|c|c|c|c|}
\hline $\begin{array}{l}\text { Zhang and } \\
\text { Pate [68] }\end{array}$ & $\begin{array}{l}\text { Ceiling } \\
\text { panels }\end{array}$ & $\begin{array}{l}\text { 2D Steady } \\
\text { Semi- } \\
\text { analytical }\end{array}$ & $\begin{array}{l}\text { Model } \\
\text { development }\end{array}$ & $\begin{array}{l}\text { A simplified model for ceiling panels is developed } \\
\text { from a numerical model }\end{array}$ \\
\hline $\begin{array}{l}\text { Chuangchid } \\
\text { and Krarti } \\
\text { [43] }\end{array}$ & $\begin{array}{l}\text { Concrete } \\
\text { Slab Floor }\end{array}$ & $\begin{array}{l}\text { 2D Periodic } \\
\text { Steady Semi- } \\
\text { analytical }\end{array}$ & $\begin{array}{l}\text { Model } \\
\text { development }\end{array}$ & $\begin{array}{l}\text { A semi-analytic model using Interzone } \\
\text { Temperature Profile Estimation (ITPE) is good for } \\
\text { TABS design and to account the effect of heat } \\
\text { loses to the ground }\end{array}$ \\
\hline Laouadi [46] & $\begin{array}{l}\text { Radiant } \\
\text { heating and } \\
\text { cooling }\end{array}$ & $\begin{array}{l}\text { 2D Semi- } \\
\text { analytical }\end{array}$ & $\begin{array}{l}\text { Model } \\
\text { development } \\
\text { and } \\
\text { integration to } \\
\text { building } \\
\text { simulation }\end{array}$ & $\begin{array}{l}\text { Couples the radiant system } 1 \mathrm{D} \text { analytical solution } \\
\text { to the tubing system } 2 \mathrm{D} \text { analytical solution with a } \\
\text { heat source node. It allows to predict tubing- } \\
\text { concrete contact surface temperature in building } \\
\text { simulation environments currently using } 1 \mathrm{D} \text { heat } \\
\text { transfer models }\end{array}$ \\
\hline Jin et al. [53] & $\begin{array}{l}\text { Radiant } \\
\text { floors }\end{array}$ & $\begin{array}{l}\text { Identification } \\
\text { model }\end{array}$ & $\begin{array}{l}\text { Model } \\
\text { development } \\
\text { and } \\
\text { validation }\end{array}$ & $\begin{array}{l}\text { A new formula is derived to estimate the floor } \\
\text { surface temperature, the results show good } \\
\text { agreement with experimental values }\end{array}$ \\
\hline $\begin{array}{l}\text { Tye-Gingras } \\
\text { and Gosselin } \\
{[76]}\end{array}$ & $\begin{array}{l}\text { Hydronic } \\
\text { radiant } \\
\text { panels }\end{array}$ & $\begin{array}{l}\text { 2D Steady } \\
\text { Semi- } \\
\text { analytical }\end{array}$ & $\begin{array}{l}\text { Model } \\
\text { development }\end{array}$ & $\begin{array}{l}\text { The developed semi-analytical model has } \\
\text { negligible errors from assumptions and is faster } \\
\text { than numerical models and more flexible than } \\
\text { analytic models }\end{array}$ \\
\hline $\begin{array}{l}\text { Ren and } \\
\text { Wright [41] }\end{array}$ & $\begin{array}{l}\text { Hollow core } \\
\text { concrete slab }\end{array}$ & $\begin{array}{l}\text { Transient } \\
\text { lumped } \\
\text { model } \\
\text { (Resistor } \\
\text { Capacitor) } \\
\end{array}$ & $\begin{array}{l}\text { Model } \\
\text { development } \\
\text { and } \\
\text { validation }\end{array}$ & $\begin{array}{l}\text { The model has good accuracy with experimental } \\
\text { measurements. The heat transfer around the } \\
\text { corners of the core ducts is } 50 \text { higher than that } \\
\text { for the plain ducts }\end{array}$ \\
\hline $\begin{array}{l}\text { Koschenz and } \\
\text { Dorer [88] }\end{array}$ & $\begin{array}{l}\text { Concrete } \\
\text { core } \\
\text { conditioning }\end{array}$ & $\begin{array}{l}\text { Transient } \\
\text { lumped } \\
\text { model } \\
\text { (Resistor) }\end{array}$ & $\begin{array}{l}\text { Model } \\
\text { development } \\
\text { and } \\
\text { validation }\end{array}$ & $\begin{array}{l}\text { The model uses a core node that represents the } \\
\text { water pipes layer and that connects both } \\
\text { surfaces of the slab. It is in good agreement with } \\
\text { FEM results and can be applied to building } \\
\text { simulation programs without modifying the code }\end{array}$ \\
\hline Liu et al. [87] & $\begin{array}{l}\text { Concrete } \\
\text { core cooling } \\
\text { slabs }\end{array}$ & $\begin{array}{l}\text { Transient } \\
\text { lumped } \\
\text { model } \\
\text { (Resistor } \\
\text { Capacitor) }\end{array}$ & $\begin{array}{l}\text { Model } \\
\text { development } \\
\text { and } \\
\text { verification }\end{array}$ & $\begin{array}{l}\text { A star type RC model is developed and verified } \\
\text { against a FEM model. For applying this model the } \\
\text { temperature fluctuation cycle should be higher } \\
\text { than } 2,51 \mathrm{~h}\end{array}$ \\
\hline $\begin{array}{l}\text { Tian et al. } \\
\text { [97] }\end{array}$ & $\begin{array}{l}\text { Concrete } \\
\text { radiant } \\
\text { cooling }\end{array}$ & $\begin{array}{l}\text { Transient } \\
\text { lumped } \\
\text { model } \\
\text { (Resistor } \\
\text { Capacitor) } \\
\end{array}$ & $\begin{array}{l}\text { Model } \\
\text { development } \\
\text { and } \\
\text { validation }\end{array}$ & $\begin{array}{l}\text { Uses core temperature layer concept and } \\
\text { reaction coefficient method for } 2 \mathrm{D} \text { heat transfer } \\
\text { model. It has an error lower than } 1,5 \% \text { compared } \\
\text { to experimental results and about } 2 \% \text { compared } \\
\text { to numerical models in the literature }\end{array}$ \\
\hline Weber [115] & TABS & $\begin{array}{l}\text { Transient } \\
\text { lumped } \\
\text { model } \\
\text { (Resistor } \\
\text { Capacitor) } \\
\end{array}$ & $\begin{array}{l}\text { Model } \\
\text { development } \\
\text { and } \\
\text { verification }\end{array}$ & $\begin{array}{l}\text { The use of matrix formulation eases the change } \\
\text { from a triangle configuration to a more easy to } \\
\text { optimize star configuration. The latter can then } \\
\text { be optimized using } w-R C \text { transform method. }\end{array}$ \\
\hline $\begin{array}{l}\text { Weber and } \\
\text { Jóhannesson } \\
{[118]}\end{array}$ & TABS & $\begin{array}{l}\text { Transient } \\
\text { lumped } \\
\text { model } \\
\text { (Resistor } \\
\text { Capacitor) } \\
\end{array}$ & $\begin{array}{l}\text { Model } \\
\text { development }\end{array}$ & $\begin{array}{l}\text { Star-network configuration its easier to optimize } \\
\text { but fail to simulate very thin slabs while triangle- } \\
\text { networks handle all configuration but are more } \\
\text { difficult to optimize }\end{array}$ \\
\hline $\begin{array}{l}\text { Weber et al. } \\
\text { [117] }\end{array}$ & TABS & \begin{tabular}{|l|} 
Transient \\
lumped \\
model \\
(Resistor \\
Capacitor) \\
\end{tabular} & $\begin{array}{l}\text { Model } \\
\text { development } \\
\text { and } \\
\text { validation }\end{array}$ & $\begin{array}{l}\text { A 2D FEM coupled to analytical solution of heat } \\
\text { and mass transfer in the pipe is accurate enough } \\
\text { to verify RC-networks coupled to filters } \\
\text { describing heat and mass flow in the pipes }\end{array}$ \\
\hline $\begin{array}{l}\text { Schmidt and } \\
\text { Jóhannesson } \\
{[111]}\end{array}$ & $\begin{array}{l}\text { Hybrid } \\
\text { building } \\
\text { constructions }\end{array}$ & $\begin{array}{l}\text { Transient } \\
\text { lumped } \\
\text { model } \\
\text { (Resistor } \\
\text { Capacitor) } \\
\end{array}$ & $\begin{array}{l}\text { Model } \\
\text { development }\end{array}$ & $\begin{array}{l}\text { The parameters of the RC model are calculated } \\
\text { using (FDFD) and the } \mathrm{W} \text {-RC-transform method. } \\
\text { The obtained RC model can be applied to } \\
\text { TRSNYS, IDA or SPARK building simulation } \\
\text { softwares }\end{array}$ \\
\hline $\begin{array}{l}\text { Schmidt and } \\
\text { Jóhannesson }\end{array}$ & $\begin{array}{l}\text { Thermally } \\
\text { activated }\end{array}$ & $\begin{array}{l}\text { Transient } \\
\text { lumped }\end{array}$ & $\begin{array}{l}\text { Model } \\
\text { development }\end{array}$ & $\begin{array}{l}\text { Incorporating optimized RC networks reduces } \\
\text { the required elements in FEM or FDM }\end{array}$ \\
\hline
\end{tabular}




\begin{tabular}{|c|c|c|c|c|}
\hline [119] & $\begin{array}{l}\text { building } \\
\text { constructions }\end{array}$ & $\begin{array}{l}\text { model } \\
\text { (Resistor } \\
\text { Capacitor) }\end{array}$ & $\begin{array}{l}\text { and } \\
\text { verification }\end{array}$ & simulations \\
\hline $\begin{array}{l}\text { Zhang et al. } \\
\text { [55] }\end{array}$ & Radiant floor & $\begin{array}{l}\text { Steady } \\
\text { lumped } \\
\text { model } \\
\text { (Resistor) }\end{array}$ & $\begin{array}{l}\text { Model } \\
\text { development } \\
\text { and } \\
\text { validation }\end{array}$ & $\begin{array}{l}\text { The model has a heat flux error around } 8-10 \% \\
\text { compared to experimental values and other } \\
\text { numerical models in the literature. The main } \\
\text { limitation is the heat transfer coefficient } \\
\text { between surface and indoor environment }\end{array}$ \\
\hline $\begin{array}{l}\text { Zhu et al. } \\
{[105]}\end{array}$ & $\begin{array}{l}\text { Pipe- } \\
\text { embedded } \\
\text { building } \\
\text { envelopes }\end{array}$ & $\begin{array}{l}\text { Transient } \\
\text { lumped } \\
\text { model } \\
\text { (Resistor } \\
\text { Capacitor) }\end{array}$ & $\begin{array}{l}\text { Model } \\
\text { development }\end{array}$ & $\begin{array}{l}\text { The parameters of the } 5 \mathrm{R} 2 \mathrm{C} \text { model are estimated } \\
\text { with a genetic algorithm using the frequency } \\
\text { characteristics obtained with a Frequency } \\
\text { Domain Finite Difference (FDFD) model. }\end{array}$ \\
\hline $\begin{array}{l}\text { Zhu et al. } \\
{[106]}\end{array}$ & $\begin{array}{l}\text { Pipe- } \\
\text { embedded } \\
\text { building } \\
\text { envelope }\end{array}$ & $\begin{array}{l}\text { Semi- } \\
\text { dynamic } \\
\text { lumped } \\
\text { model } \\
\text { (Resistor } \\
\text { Capacitor) }\end{array}$ & $\begin{array}{l}\text { Model } \\
\text { development }\end{array}$ & $\begin{array}{l}\text { Adds the Number of Transfer Units (NTU) } \\
\text { technique to a 5R2C model to allow calculation } \\
\text { of the heat transfer along the pipe. Compared to } \\
\text { a CFD model the error is lower than } 5 \% \text { and the } \\
\text { computational effort is reduced from several } \\
\text { hours on the CFD to } 10 \text { min in the simplified } \\
\text { model }\end{array}$ \\
\hline $\begin{array}{l}\text { Chae and } \\
\text { Strand [82] }\end{array}$ & $\begin{array}{l}\text { Hollow core } \\
\text { slab }\end{array}$ & $\begin{array}{l}\text { Transfer } \\
\text { function }\end{array}$ & $\begin{array}{l}\text { Model } \\
\text { development } \\
\text { and } \\
\text { verification }\end{array}$ & $\begin{array}{l}\text { The model can be included to EnergyPlus easing } \\
\text { the simulation of ventilated slabs in different } \\
\text { building configuration and allowing the } \\
\text { comparison with other HVAC systems }\end{array}$ \\
\hline $\begin{array}{l}\text { Ferkl and } \\
\text { Šyroky [70] }\end{array}$ & $\begin{array}{l}\text { Ceiling } \\
\text { radiant } \\
\text { cooling }\end{array}$ & $\begin{array}{l}\text { Identification } \\
\text { model }\end{array}$ & $\begin{array}{l}\text { Identification } \\
\text { comparison }\end{array}$ & $\begin{array}{l}\text { Subspace state identification method is faster to } \\
\text { implement and easier to tune but ARMAX } \\
\text { method still yelds better results in systems with } \\
\text { high noise }\end{array}$ \\
\hline $\begin{array}{l}\text { Prívara et al. } \\
\text { [74] }\end{array}$ & $\begin{array}{l}\text { Ceiling } \\
\text { radiant } \\
\text { heating and } \\
\text { cooling }\end{array}$ & $\begin{array}{l}\text { Identification } \\
\text { model }\end{array}$ & $\begin{array}{l}\text { Identification } \\
\text { comparison } \\
\text { and } \\
\text { improvement }\end{array}$ & $\begin{array}{l}\text { MRI improves the model quality compared to } \\
\text { one-step ahead, in cases with collinearity the } \\
\text { enhanced MRI-PLS shows better performance }\end{array}$ \\
\hline
\end{tabular}

\section{TABS control strategies}

The dynamic nature of TABS makes its control challenging. Much research has been conducted to design and optimize control strategies under different conditions. Focus is on maintaining good thermal comfort conditions and reducing energy use, but research also studies the coordination with ventilation and the optimization of the use of free-energy through lowenergy sources [65].

The controlled variables for TABS are the supply temperature and the flow in the ducts or pipes $[48,60]$. The magnitude of both parameters can be interchanged to obtain the required power [90]. The most common controlling parameters are outdoor temperature with or without indoor temperature feedback and indoor dew-point $[48,51,85]$ and the relation between controlled variables and controlling parameters is defined by the control strategies. Advanced control strategies might use weather forecast or historical data to define the controlled variables. Also the operation of TABS can be continuous or intermittent [50].

\subsection{Control limitations}

Low thermal mass TABS, as ceiling panels or radiant floors, have a response time fast enough to react to changes in room conditions, allowing for individual room control. However, TABS with high thermal mass, as hollow core slabs or active concrete core, have significant slow response time. Peak loads cannot be dealt instantaneously, however, TABS can buffer energy during the day due to thermal mass [155]. Under these conditions, individual room control is 
not possible, buildings with high thermal mass TABS are commonly divided in zones with similar heat gains [121], where each zone might have its own controlling parameters.

As previously stated, TABS supply system topology also affects to building control $[95,121]$. It can give flexibility to supply different temperature at each zone and even supply heating and cooling simultaneously if required. The system topology has to be taken into account when defining the control strategy to avoid comfort and energy squandering issues related to rooms with different heat gains. The topology might allow circulation, which might be needed in some strategies for homogenisation of room temperature with different heat gains.

As pointed out in Table 2 on section 4, TABS heating and cooling capacity is limited depending on operational mode and position. The temperature of a certain surface could be limited to certain maximum or minimum value to avoid discomfort $[48,51]$.

Finally, buildings always require ventilation for hygienic reasons. Ventilation can cause additional heat loses or can be used to supply auxiliary energy to complement TABS, and in addition, it is also used to control humidity. Synchronisation between TABS and ventilation is an important point to take into account in the control design $[10,51,67]$.

\subsection{ON/OFF criterions}

The ON/OFF criterions establish when there is flow to TABS or when activation of heating or cooling is done. Day-long continuous operation is possible, where supply temperature or variable flow regulate indoor temperature $[33,36,98]$. However, limited operation schedules reduce energy consumption [90]. The peak load shifting ability of heavy weight TABS can be used to operate in energy production favourable periods $[8,33,100,102]$. On the other side, radiant floors or ceiling panels can be used to react to heat loads during occupancy. Intermittent operation can improve heat transfer and reduce operation time $[14,50,81]$. Moreover, circulation in TABS circuits without active cooling or heating, is used to homogenise temperatures or to select operation mode in advanced controls.

ON/OFF criterion is usually the most basic parameter of a TABS control.

\subsubsection{Three step control in dependency of the room temperature}

This control, also known as bang-bang on/off or hysteresis control, uses a control parameter, usually room air temperature, to set pumps operation mode. Pumps are set "ON" to reach the set-point temperature. When set-point is exceeded the pumps are set "OFF". To avoid constant switching hysteresis can be implemented with a dead band. Supply temperature is maximum in heating mode and minimum in cooling mode. This is a very simple control that does not integrate information regarding the dynamics of the system.

Cho and Zaheer-uddin [47] studied ON/OFF control on radiant floor heating with air room temperature feedback obtaining good control of room air temperature, with fluctuation of only 2 ․ C. Switching the control parameter in short periods from air room temperature to slab surface temperature obtained the same room air temperature control and reduced temperature variation on slab surface. In an ON/OFF control switching, heating and cooling set-point temperature is maintained with low margin, however, surface temperature varies greatly causing discomfort $[48,51]$. Sourbron et al. [52] showed that wider dead band extended 
the time to switch from heating to cooling and resulted in less energy consumption with same comfort conditions. Some studies $[98,124]$ extended ON criterion to operative temperature exceeding set-point temperature and the average outdoor temperature of the previous day exceeding a certain value.

Although ON/OFF control is very simple to apply and achieves good comfort conditions it is not the most optimal for energy use [51,52].

\subsubsection{Night operation}

TABS can be operated on night-time or according to occupancy periods because of its thermal storage capacity. Night-time operation might have the advantage of operation in low cost energy periods [113] and of free cooling with cool air [7,23,90,100]. Ma et al. [33] showed that night-time operation kept an average indoor temperature $1 \mathrm{~K}$ higher than continuous operation, however, temperature fluctuations had the same amplitude in both operation modes. In another study [94] the temperature rise was $2.5 \mathrm{~K}$, a fluctuation that kept temperatures inside comfort range [27].

\subsubsection{Intermittent operation}

The objective of intermittent operation is to release the heat in pulses to the TABS by regulating the periods when flow circulates through the TABS. In cooling mode when the fluid flow is stopped the heat will continue to flow toward the cooler centre, where the temperature will increase. When the flow starts again, it will operate with a larger temperature gradient between water and concrete, then it will transfer more heat in a shorter time $[14,50,81]$. The pulses can be fixed time periods of intermittent operation [14] or variable time periods [50]. These last can be defined with different techniques like Pulse Width Modulation (PWM) and Model Predictive control, which are advanced controls that define the length of the pulse and are explained on following sections. The results show that intermittency reduces energy consumption and it can even reduce room temperature drift $[14,36,80]$.

Cho and Zaheer-uddin [50] tested an intermittent operation strategy with pulses length defined by a forecast prediction model and compared it to a conventional intermittent control achieving $10-20 \%$ energy savings.

\subsection{Supply temperature control}

Supply temperature is an essential parameter to achieve good energy performance and comfort conditions with TABS. Usually the regulation of the supply temperature is the base for any control strategy.

Theoretically TABS can work using the self-regulating effect. If TABS are supplied at constant temperature then heating or cooling is supplied when the indoor temperature is respectively below or above the supply temperature. However, the self-regulating effect is not enough to compensate large thermal variation and a control of supply temperature is needed [121]. In the case of floor cooling, Lim et al. [60] concluded that control based on supply temperature performed better than controls based on flow control. 
Usually supply temperature is defined according operational experience. Lim [16] et al. defined a supply temperature of $29^{\circ} \mathrm{C}$ for heating and $19{ }^{\circ} \mathrm{C}$ after measurement and simulation of heating and cooling in a building with concrete core activation. For cooling, a supply temperature equal to dew point temperature in the room maximizes the cooling capacity avoiding condensation issues [14,98]. For TABS heating in well insulated buildings supply temperatures higher than $45-55^{\circ} \mathrm{C}$ squander energy [99].

Supplying at constant temperature causes significant room temperature fluctuations [14] so control of supply temperature with heating and cooling curves is common [5].

\subsubsection{Supply water temperature curves}

The controls of supply water temperature with heating and/or cooling curve define the supply temperature as a function of a parameter, commonly outdoor temperature. The curves have higher supply temperature for low outdoor temperatures and lower supply temperatures for high outdoor temperatures. In order to increase the efficiency, it is need to select the curves according to the building mass and thermal losses [5]. Different studies $[14,48,51]$ showed that outdoor compensated supply temperature gives more stable conditions than on/off and variable flow controls. Dead band is also useful for reducing energy consumption with supply temperature curves [32].

Instantaneous outdoor temperature is the most common independent variable for supply temperature curves. Alternatively, the average temperature of the previous hours or the average temperature of the predicted hours was used with concrete core activation although no improvement was found even with perfect predicted data [27]. Wit and Wise [121] used the Running Mean Outdoor Temperature (RMOT) which averages with different weight the average temperature of the current day and those of the previous.

Without affecting the performance, the supply curve can either define the supply temperature or the average fluid temperature $[14,32]$, where the supply temperature is also related to the temperature drop inside the TABS.

\subsubsection{Unknown But Bounded (UBB)}

The UBB is a method for designing heating and cooling curves of TABS that was implemented in a project for developing a control for TABS [89]. Heat gains are uncertain in present buildings and TABS are slow responsive systems. The UBB calculates the upper and lower bounds of heat gains and defines the heating and cooling curves so the operative temperature is maintained inside the acceptable range $[15,34]$. The calculation needs the knowledge of the physical characteristics of the building and the TABS. This method also helps to define the zones of a building by identifying rooms with different heat gains boundaries.

Saelens et al. [124] used the UBB control to study the influence of occupants behaviour in a building with TABS. The variable temperature control helped in reducing cooling load and overheating issues. It was also pointed that management of shading devices affects the control performance as it influences on solar gains, thus automated control of shading was proposed. Arteconi et al. [120] studied the effect of Demand Side Management (DSM) on a building with TABS controlled with UBB method. TABS cope well with the superimposed external request 
and good comfort conditions were maintained, but DSM did not reduce TABS energy consumption.

\subsection{Pulse Width Modulation (PWM)}

Pulse Width Modulation (PWM) is a discontinuous operation control developed as part of TABS control project [89] that also involved UBB supply temperature control. PWM [93] operates on cyclic activation periods. At the beginning of each cycle the activation time of pumps is calculated using the supply temperature defined by UBB and the actual temperature of the fluid as input data. Each activation period starts with a purge where the fluid circulates inside the TABS, without active heating or cooling. After each purge, the control defines if circulation is continued, if pumps are switched off or if active cooling/heating is needed. In case of active conditioning, the duration of the pulse is also defined. The proposed control has four modules [96], a sequence controller, an outside compensated temperature control room feedback, and the PWM. The sequence controller for defining heating or cooling season and the module to define the supply temperature based on UBB method are compulsory modules. Room temperature feedback and Pulse Width Modulation modules are optional modules. Lehmann [36] et al. obtained savings of $50 \%$ of electrical energy consumption of pumps with PWM compared to continuous operation.

\subsection{Model Predictive Control (MPC)}

The reduction of the cost of data processing, storage and communication makes the design and implementation of advanced controller feasible [156]. MPC is one the most promising controls for HVAC, TABS included. MPC uses an identified model system to predict future states and generates a control vector that minimizes a certain cost function over a prediction horizon in presence of disturbance and constraint. Only the first element of the control vector is used, the rest are discarded. At each new time step all the calculation process is done again.

Privara et al. [73] applied MPC to a building equipped with radiant heating panels. The model for the control was obtained with discrete-time linear time invariant stochastic model considering it as a Kalman filter. The results showed that classic identification techniques are insufficient for modelling the control, the performance of the control improved when measured data of the building was used in the identification. Compared to the weather compensated control, the MPC showed savings potential about 17-25\%. MPC also tracked setpoint temperature better than weather compensated control, it did not have fast changes in operation mode and it reduced energy peaks. Similar results were obtained by Sourbron et al. [86] with a MPC using a statistical identification model which reduced energy consumption by $15 \%$ compared to a reference controller. Also savings of $20 \%$ were obtained by Prívara et al. [74] applying MPC to an actual office building.

Applied to radiant cooling slabs Feng et al. [80] developed a first order dynamic model. The MPC model defines the opening of the valve with an algorithm that minimizes energy consumption and time outside comfort limits. It calculates external disturbance with the expected value of predicted weather data, as it considers certainty equivalence as adequate for the radiant slab problem. Simulations showed that MPC control could maintain EN 15251 Category II [134] thermal comfort level more than 95\% of the occupied hours for all zones while the heuristic method thermal comfort could not be maintained in all zones. MPC 
reduced the cooling tower energy consumption by $55 \%$ and pumping power consumption by $25 \%$.

According to Zakula et al. [157] there are not current commercial tools for MPC simulation and most of the research done involved significant modification of existing building simulation programs. That is the motivation for developing a Modelling Environment (ME) for simulation of building with HVAC controlled with MPC. The ME uses TRNSYS for the detailed building simulation and a MATLAB algorithm for the optimization of the control settings. It is a modular environment that allows simulation of different types of HVAC, TABS included, and flexible MPC parameters.

\subsection{Adaptive and predictive controls}

Adaptive and predictive controls are techniques that adapt a controlled system with parameters which might vary or are uncertain. The bounds of the system are not required " $a$ priori" because adaptive controls can modify the control law by themselves.

A predictive control was developed by Chen [49] in the form of a Generalised Predictive Control (GPC). The control was applied to a test room equipped with floor radiant heating. The model used for the GPC was developed from a z-transfer function were the operative temperature was the controlled variable. The parameter were identified with a recursive least squares algorithm and reorganised in the Controlled Auto-Regressive and Integrated MovingAverage (CARIMA). It formulates a j-step-ahead predictor. The GPC control performance was compared to an on-off controller without dead band and to an on-off PI controller. The GPC showed the best control performance with the lower rise time to set-point and a null offset to set-point.

A more developed control was presented by Schmelas et al. [85] in the form of the AMLR, an adaptive and predictive algorithm for control of TABS. The control is based in multiple linear regressions and uses Ordinary Least Squares method (OLS) for calculating the regression coefficients. It uses weather data from the previous 15 days and the weather forecast of the following $24 \mathrm{~h}$ in conjunction of a RC network model of TABS to calculate the package of heat to be supplied or extracted from the building. The control uses the thermal storage capacity of TABS as it charges the heat or cold calculated in a single pulse at the beginning of the day. Compared to outside temperature compensated supply temperature, AMRL achieved better comfort conditions. Its main advantage is a self-learning capacity that allows it to be adapted to variations of internal load charges.

\subsection{Gain Scheduling Control (GSC)}

Gain Scheduling Controls are an evolution of PID controls that improve the management of a process with gains and time constants that change according to the current value of the process variable. Heat flux on TABS strongly depends on the temperature gradient between the supply temperature and the room temperature. Additionally TABS have significant thermal lags. For this reason GSC capacity to adapt changes on the scheduling variable makes it promising for TABS control.

Krzaczek and Kowlczuk $[42,108]$ presented a controller based on Fussy Mixing Gain Scheduling (FMGS) for TB coupled to a geothermal system with different temperature levels. The fuzzy 
mixing in the FMGS is used for both scheduling controller gains and fuzzy mixing of fluids flowing from geothermal heat sources. The scheduling variable is the solar-air equivalent outdoor temperature and the controlled variable is the TB active layer temperature. A fuzzy mixing equation interpolates the contribution of each operation mode to the calculation of supply temperature and mass flow by defining FMGS-PI controller. A decision module is used to block the controller integer part on mass flow calculation to avoid wind-up. An interference engine block is used to introduce rule base knowledge of TB performance that can avoid flow reversal. A time lag block represents the heat capacitance effect on delaying the heat waves. Simulations showed that the controller kept the mass flow inside optimum range and it also exploited effectively all the multiple geothermal heat sources.

\subsection{TABS control coupled to dehumidification and ventilation}

TABS operation interacts with the ventilation system thus the control and coordination of both systems have to be considered. The ventilation system can supply additional cooling or heating on peak demand or it can reduce humidity to avoid condensation on cooled surfaces then keeping TABS cooling performance high. Ventilation strategies are dependent on climatic conditions [79].

Lim et al. [51] proposed that for radiant floor cooling in domestic buildings, TABS and ventilation system are better operated independently. However, Tian and Love [30] found energy squandering caused by simultaneous TABS cooling and ventilation air heating. TABS with ventilation have faster response times and maintain more stable conditions $[79,61]$. Supply air temperature and surface temperature set-points are the essential parameters to coordinate ventilation and TABS [10]. Ventilation with outdoor air can be enough to maintain comfort conditions and avoid condensation [100] but better results were obtained with supply air temperature management [114]. Lim et al. proposed TABS to deal with a maximum of $50 \%$ of the cooling load in building operation [16]. Meierhans [7] provided specific cooling loads values for combined ventilation and radiant cooling, showing that ventilation at constant temperature on continuous operation dealt with all latent load and $5 \mathrm{~W} / \mathrm{m}^{2}$ of sensible load while concrete core cooling operating $7 \mathrm{~h}$ over a day achieved an average of $15 \mathrm{~W} / \mathrm{m}^{2}$. In contrast ceiling panels were found to deal with up to $50 \mathrm{~W} / \mathrm{m}^{2}$ of sensible cooling load while its associated ventilation dealt with all latent load and $16-19 \mathrm{~W} / \mathrm{m}^{2}$ of sensible load [72]. The research done showed that the risk of condensation is greatly reduced with ventilation $[61,72$, 79]. To further reduce this issue, it was proposed to start dehumidification one hour earlier than cooling [67]. 
Table 4: Summary of TABS control strategies

\begin{tabular}{|c|c|c|c|c|}
\hline Reference & System & Control type & Application & Main findings \\
\hline $\begin{array}{l}\text { Cho and } \\
\text { Zaheer- } \\
\text { uddin [47] }\end{array}$ & $\begin{array}{l}\text { Radiant } \\
\text { floor } \\
\text { heating }\end{array}$ & ON/OFF & $\begin{array}{l}\text { Full room } \\
\text { experimental } \\
\text { laboratory } \\
\text { study }\end{array}$ & $\begin{array}{l}\text { Alternating the control parameter from indoor } \\
\text { temperature to surface temperature improve } \\
\text { temperature regulation }\end{array}$ \\
\hline $\begin{array}{l}\text { Lim et al. } \\
{[48]}\end{array}$ & $\begin{array}{l}\text { Radiant } \\
\text { floor } \\
\text { cooling }\end{array}$ & $\begin{array}{l}\text { ON/OFF and } \\
\text { Supply } \\
\text { temperature } \\
\text { curves }\end{array}$ & $\begin{array}{l}\text { Room } \\
\text { simulation }\end{array}$ & $\begin{array}{l}\text { Continuous operation with supply temperature } \\
\text { curves has better room temperature stability and } \\
\text { les condensation occurrence }\end{array}$ \\
\hline $\operatorname{Lim}_{[51]}$ et al. & $\begin{array}{l}\text { Radiant } \\
\text { floor } \\
\text { cooling }\end{array}$ & $\begin{array}{l}\text { ON/OFF, } \\
\text { variable } \\
\text { flow, supply } \\
\text { temperature } \\
\text { curves and } \\
\text { ventilation }\end{array}$ & $\begin{array}{l}\text { Room } \\
\text { simulation }\end{array}$ & $\begin{array}{l}\text { With supply temperature curves the } \\
\text { dehumidification system operates less than half } \\
\text { the time compared to ON/OFF control }\end{array}$ \\
\hline $\begin{array}{l}\text { Sourbron et } \\
\text { al. [52] }\end{array}$ & $\begin{array}{l}\text { Radiant } \\
\text { floor } \\
\text { heating and } \\
\text { TABS }\end{array}$ & ON/OFF & $\begin{array}{l}\text { Office } \\
\text { building } \\
\text { monitoring } \\
\text { and room } \\
\text { simulation }\end{array}$ & $\begin{array}{l}\text { Increasing dead band reduces energy squandering } \\
\text { from switching from cooling to heating. Night } \\
\text { operation reduced up to } 85 \% \text { energy use compared } \\
\text { to room feedback control }\end{array}$ \\
\hline $\begin{array}{l}\text { Ma et al. } \\
{[33]}\end{array}$ & TABS & $\begin{array}{l}\text { Night-time } \\
\text { ON/OFF }\end{array}$ & $\begin{array}{l}\text { Office } \\
\text { building } \\
\text { simulation }\end{array}$ & $\begin{array}{l}\text { The temperature rise with night-time is the same as } \\
\text { with continuous operation but with slightly higher } \\
\text { average temperature }\end{array}$ \\
\hline $\begin{array}{l}\text { Rijksen et al. } \\
\text { [94] }\end{array}$ & $\begin{array}{l}\text { Concrete } \\
\text { core cooling }\end{array}$ & $\begin{array}{l}\text { Night-time } \\
\text { ON/OFF }\end{array}$ & $\begin{array}{l}\text { Office } \\
\text { building } \\
\text { monitoring } \\
\text { and } \\
\text { simulation }\end{array}$ & $\begin{array}{l}\text { With night-time operation of TABS the temperature } \\
\text { rise during occupancy period was kept below } 2.5 \mathrm{~K}\end{array}$ \\
\hline $\begin{array}{l}\text { Dossi et al. } \\
{[113]}\end{array}$ & $\begin{array}{l}\text { Thermal } \\
\text { slabs }\end{array}$ & ON/OFF & $\begin{array}{l}\text { Office } \\
\text { building } \\
\text { simulation }\end{array}$ & $\begin{array}{l}\text { Massive radiant systems help to reduce peak loads } \\
\text { and can operate at low cost periods }\end{array}$ \\
\hline Olesen [14] & $\begin{array}{l}\text { Water } \\
\text { based } \\
\text { radiant } \\
\text { systems }\end{array}$ & $\begin{array}{l}\text { Intermittent } \\
\text { ON/OFF and } \\
\text { supply } \\
\text { temperature } \\
\text { curve }\end{array}$ & $\begin{array}{l}\text { Office } \\
\text { building } \\
\text { simulation }\end{array}$ & $\begin{array}{l}\text { Intermittent operation reduces temperature } \\
\text { fluctuation and energy consumption }\end{array}$ \\
\hline $\begin{array}{l}\text { Cho and } \\
\text { Zaheer- } \\
\text { uddin [50] }\end{array}$ & $\begin{array}{l}\text { Radiant } \\
\text { floor } \\
\text { heating }\end{array}$ & $\begin{array}{l}\text { Intermittent } \\
\text { ON/OFF }\end{array}$ & $\begin{array}{l}\text { Room } \\
\text { simulation } \\
\text { and } \\
\text { monitoring }\end{array}$ & $\begin{array}{l}\text { Intermittent operation with pulses defined with } \\
\text { forecast reduce energy use }\end{array}$ \\
\hline $\begin{array}{l}\text { Lim et al. } \\
{[60]}\end{array}$ & $\begin{array}{l}\text { Radiant } \\
\text { floor }\end{array}$ & $\begin{array}{l}\text { Supply } \\
\text { temperature } \\
\text { curve and } \\
\text { ON/OFF } \\
\end{array}$ & $\begin{array}{l}\text { Residential } \\
\text { building } \\
\text { simulation }\end{array}$ & $\begin{array}{l}\text { Supply temperature controls have better } \\
\text { temperature fluctuations than flow controls }\end{array}$ \\
\hline $\begin{array}{l}\text { Lim et al. } \\
\text { [16] }\end{array}$ & TABS & $\begin{array}{l}\text { Supply } \\
\text { temperature } \\
\text { control }\end{array}$ & $\begin{array}{l}\text { Office } \\
\text { building } \\
\text { simulation } \\
\text { and } \\
\text { monitoring }\end{array}$ & $\begin{array}{l}\text { Establish operational guidelines through field } \\
\text { experience }\end{array}$ \\
\hline $\begin{array}{l}\text { Hauser et al. } \\
\text { [98] }\end{array}$ & $\begin{array}{l}\text { Concrete } \\
\text { slab cooling }\end{array}$ & $\begin{array}{l}\text { Supply } \\
\text { temperature } \\
\text { control }\end{array}$ & $\begin{array}{l}\text { Office } \\
\text { building } \\
\text { simulation }\end{array}$ & $\begin{array}{l}\text { Control with supply temperature equal to dew- } \\
\text { point temperatures achieve good comfort }\end{array}$ \\
\hline $\begin{array}{l}\text { Sarbu and } \\
\text { Sebarchievici } \\
\text { [99] }\end{array}$ & $\begin{array}{l}\text { Radiant } \\
\text { surface }\end{array}$ & $\begin{array}{l}\text { Supply } \\
\text { temperature } \\
\text { control }\end{array}$ & $\begin{array}{l}\text { Residential } \\
\text { building } \\
\text { simulation }\end{array}$ & $\begin{array}{l}\text { For radiant surface systems there is no need of } \\
\text { supply temperature higher than } 45-55^{\circ} \mathrm{C}\end{array}$ \\
\hline Olesen [32] & $\begin{array}{l}\text { Thermally } \\
\text { activated } \\
\text { slab }\end{array}$ & $\begin{array}{l}\text { Supply } \\
\text { temperature } \\
\text { curve }\end{array}$ & $\begin{array}{l}\text { Office room } \\
\text { simulation }\end{array}$ & $\begin{array}{l}\text { The best performance is obtained by supply } \\
\text { temperature curve with outside temperature as } \\
\text { control parameter. }\end{array}$ \\
\hline $\begin{array}{l}\text { Gwerder et } \\
\text { al. [15] }\end{array}$ & TABS & $\begin{array}{l}\text { Supply } \\
\text { temperature } \\
\text { curve UBB }\end{array}$ & $\begin{array}{l}\text { Office } \\
\text { building } \\
\text { simulation }\end{array}$ & $\begin{array}{l}\text { UBB facilitates TABS dimensioning and control } \\
\text { definition. Comfort can be maintained in a range of } \\
\text { internal gains }\end{array}$ \\
\hline
\end{tabular}




\begin{tabular}{|c|c|c|c|c|}
\hline $\begin{array}{l}\text { Tödli et al. } \\
\text { [34] }\end{array}$ & TABS & $\begin{array}{l}\text { Supply } \\
\text { temperature } \\
\text { curve UBB } \\
\end{array}$ & $\begin{array}{l}\text { Design } \\
\text { method }\end{array}$ & $\begin{array}{l}\text { Defines a design and dimensioning flow chart using } \\
\text { UBB supply temperature curves }\end{array}$ \\
\hline $\begin{array}{l}\text { Saelens } \\
\text { al. [124] }\end{array}$ & TABS & $\begin{array}{l}\text { Unknown } \\
\text { But Bounded } \\
\text { supply } \\
\text { temperature } \\
\text { curves }\end{array}$ & $\begin{array}{l}\text { Office } \\
\text { building } \\
\text { simulation }\end{array}$ & $\begin{array}{l}\text { Occupants behaviour have great impact on cooling } \\
\text { demand although TABS can cope with the demand } \\
\text { if good solar protection is present }\end{array}$ \\
\hline $\begin{array}{l}\text { Arteconi et } \\
\text { al. [120] }\end{array}$ & TABS & $\begin{array}{l}\text { Supply } \\
\text { temperature } \\
\text { curve UBB }\end{array}$ & $\begin{array}{l}\text { Office } \\
\text { building } \\
\text { simulation } \\
\text { and } \\
\text { monitoring } \\
\end{array}$ & $\begin{array}{l}\text { TABS controlled with UBB cope well with } \\
\text { superimposed demand to manage energy demand }\end{array}$ \\
\hline $\begin{array}{l}\text { Gwerder et } \\
\text { al. [93] }\end{array}$ & $\begin{array}{l}\text { Concrete } \\
\text { core } \\
\text { conditioning }\end{array}$ & $\begin{array}{l}\text { PWM and } \\
\text { supply } \\
\text { temperature } \\
\text { curves UBB }\end{array}$ & $\begin{array}{l}\text { Room } \\
\text { simulation } \\
\text { and } \\
\text { laboratory } \\
\text { testing }\end{array}$ & $\begin{array}{l}\text { The PWM design method and control is accurate } \\
\text { enough and allows shifting switch-on times to high } \\
\text { energy efficiency periods }\end{array}$ \\
\hline $\begin{array}{l}\text { Lehmann et } \\
\text { al. [36] }\end{array}$ & $\begin{array}{l}\text { Concrete } \\
\text { core } \\
\text { conditioning }\end{array}$ & $\begin{array}{l}\text { PWM and } \\
\text { supply } \\
\text { temperature } \\
\text { curves UBB }\end{array}$ & $\begin{array}{l}\text { Office } \\
\text { building } \\
\text { simulation }\end{array}$ & $\begin{array}{l}\text { PWM control reduces electric energy use by } 50 \% \\
\text { compared to an standard control }\end{array}$ \\
\hline Chen [49] & $\begin{array}{l}\text { Floor } \\
\text { radiant } \\
\text { heating }\end{array}$ & MPC & $\begin{array}{l}\text { Room } \\
\text { simulation } \\
\text { and } \\
\text { monitoring }\end{array}$ & $\begin{array}{l}\text { The GPC control has faster response and less set- } \\
\text { point deviation compared to ON/OFF and PI } \\
\text { controls }\end{array}$ \\
\hline $\begin{array}{l}\text { Prívara et al. } \\
\text { [73] }\end{array}$ & $\begin{array}{l}\text { Ceiling } \\
\text { radiant } \\
\text { heating } \\
\text { panels }\end{array}$ & MPC & $\begin{array}{l}\text { Office } \\
\text { building } \\
\text { monitoring }\end{array}$ & $\begin{array}{l}\text { MPC control reduces energy use by } 17-24 \% \text { and } \\
\text { tracks set-point temperature better than a weather } \\
\text { compensated control }\end{array}$ \\
\hline $\begin{array}{l}\text { Sourbron et } \\
\text { al. [86] }\end{array}$ & $\begin{array}{l}\text { Concrete } \\
\text { core } \\
\text { activation }\end{array}$ & MPC & $\begin{array}{l}\text { Office } \\
\text { building } \\
\text { simulation }\end{array}$ & $\begin{array}{l}\text { MPC control using identification model reduces } \\
15 \% \text { energy use compared to a reference controller }\end{array}$ \\
\hline $\begin{array}{l}\text { Prívara et al. } \\
\text { [74] }\end{array}$ & $\begin{array}{l}\text { Ceiling } \\
\text { radiant } \\
\text { heating } \\
\text { panels }\end{array}$ & MPC & $\begin{array}{l}\text { Office } \\
\text { building } \\
\text { monitoring }\end{array}$ & $\begin{array}{l}\text { MPC control with a model identified with MRI } \\
\text { method reduced by } 20 \% \text { energy use for heating }\end{array}$ \\
\hline $\begin{array}{l}\text { Feng et al. } \\
{[80]}\end{array}$ & $\begin{array}{l}\text { Radiant } \\
\text { slabs }\end{array}$ & MPC & $\begin{array}{l}\text { Office } \\
\text { building } \\
\text { simulation } \\
\end{array}$ & $\begin{array}{l}\text { MPC control was able to maintain comfort for all } \\
\text { building zones }\end{array}$ \\
\hline $\begin{array}{l}\text { Schemlas et } \\
\text { al. [85] }\end{array}$ & $\begin{array}{l}\text { Concrete } \\
\text { core } \\
\text { activation }\end{array}$ & $\begin{array}{l}\text { Adaptive and } \\
\text { predictive }\end{array}$ & $\begin{array}{l}\text { Room } \\
\text { simulation } \\
\text { and } \\
\text { laboratory } \\
\text { monitoring } \\
\end{array}$ & $\begin{array}{l}\text { The proposed control achieve better comfort } \\
\text { conditions than supply temperature curves with } \\
\text { simpler computation than MPC }\end{array}$ \\
\hline $\begin{array}{l}\text { Krzaczek and } \\
\text { Kowalczuk } \\
{[42]}\end{array}$ & TB & GSC & $\begin{array}{l}\text { TB } \\
\text { simulation }\end{array}$ & $\begin{array}{l}\text { The control maintains the TB active layer at } 17{ }^{\circ} \mathrm{C} \\
\text { with a variation lower than } 0.2{ }^{\circ} \mathrm{C}\end{array}$ \\
\hline $\begin{array}{l}\text { Krzaczek and } \\
\text { Kowalczuk } \\
{[108]}\end{array}$ & TB & GSC & $\begin{array}{l}\text { TB } \\
\text { simulation }\end{array}$ & $\begin{array}{l}\text { Control improvement reduced TB active layer } \\
\text { variation to } 0.07^{\circ} \mathrm{C}\end{array}$ \\
\hline $\begin{array}{l}\text { Tian and } \\
\text { Love [30] }\end{array}$ & $\begin{array}{l}\text { Radiant slab } \\
\text { cooling }\end{array}$ & $\begin{array}{l}\text { ON/OFF } \\
\text { control and } \\
\text { ventilation }\end{array}$ & $\begin{array}{l}\text { Office } \\
\text { building } \\
\text { simulation } \\
\end{array}$ & $\begin{array}{l}\text { Radiant cooling savings are larger in dry hot } \\
\text { climates than in cold moist climates }\end{array}$ \\
\hline $\begin{array}{l}\text { Song et al. } \\
{[61]}\end{array}$ & $\begin{array}{l}\text { Radiant } \\
\text { floor } \\
\text { cooling }\end{array}$ & $\begin{array}{l}\text { Supply } \\
\text { temperature } \\
\text { curves and } \\
\text { ventilation }\end{array}$ & $\begin{array}{l}\text { Laboratory } \\
\text { room } \\
\text { monitoring } \\
\text { and building } \\
\text { simulation }\end{array}$ & $\begin{array}{l}\text { Integration of radiant cooling and dehumidification } \\
\text { increase responsiveness to internal load changes } \\
\text { and avoids condensation }\end{array}$ \\
\hline $\begin{array}{l}\text { Henze et al. } \\
{[10]}\end{array}$ & TABS & $\begin{array}{l}\text { Supply } \\
\text { temperature } \\
\text { curves and }\end{array}$ & $\begin{array}{l}\text { Office } \\
\text { building } \\
\text { simulation }\end{array}$ & $\begin{array}{l}\text { The full VAV systems used } 20 \% \text { more energy than } \\
\text { the coordinated TABS + VAV system }\end{array}$ \\
\hline
\end{tabular}




\begin{tabular}{|l|l|l|l|l|}
\hline & & ventilation & & \\
\hline Fellin et al. & Thermal & Supply & Office & Handled air could help thermal slab performance \\
[114] & slab & $\begin{array}{l}\text { temperature } \\
\text { control and } \\
\text { ventilation }\end{array}$ & $\begin{array}{l}\text { simulation } \\
\end{array}$ & \\
\hline
\end{tabular}

\section{Conclusions}

TABS are a promising technology for reducing the energy use in the building sector. The main challenges this technology faces are the heat transfer calculation, the dimensioning integrated to building design and the development of efficient controls. This paper reviews the TABS generalities and the research on heat transfer calculation models, the simulation models and the control strategies.

TABS simulation models have been essential to study their performance and to improve both their design and control. Many types of models have been developed with different application purposes and different degrees of accuracy. From 1D, 2D and 3D numerical or analytical models, mathematical correlations and simplified models have been developed. Detailed numerical models as FDM, FVM or FEM give the most accurate results and have been used for model verification. However, many simplified models have good accuracy in the application range while reducing significantly the computational effort. The latter are usually integrated in building simulation packages and in control strategies. Though steady state models have been used in research, it has been proved that the dynamic behaviour of TABS requires transient models for accurate studies.

Control strategies for TABS directly affect the comfort conditions and energy saving potential. Simple strategies can obtain good comfort conditions, but for reducing energy demand and fully exploiting renewable energies it is required to use strategies that take into account the characteristics of the system. Control of supply temperature with heating and cooling curves is common for most TABS controls. More advanced controls use heating curves as the base of its control to later calculate the energy that has to be supplied and the periods of activation. Control strategies are essential for optimizing the use of renewable energy sources. The controls have to consider the storage capacity of TABS to estimate the requirements of energy in advance so renewable energy sources are used when available.

Research has proved the great energy savings potential and $\mathrm{CO}_{2}$ emission reduction that can be achieved with TABS. Still research is required to solve some design issues and to encourage application of TABS in refurbishment. Coordination of TABS control with ventilation and heat gains control as shading systems or lighting is also a point for further research.

\section{Acknowledgements}

The authors would like to thank the Catalan Government for the quality accreditation given to their research group (2014 SGR 123). This projects has received funding from the European Commission Seventh Framework Programme (FP/2007-2013) under Grant agreement № PIRSES-GA-2013-610692 (INNOSTORAGE) and from European Union's Horizon 2020 research and innovation programme under grant agreement № 657466 (INPATH-TES) and from EEAGrants under grant IDI-20140914. The work was partially funded by the Spanish government 
grant ENE2015-64117-C5-1-R and grant ENE2015-64117-C5-3-R. Alvaro de Gracia would like to thank Ministerio de Economia y Competitividad de España for Grant Juan de la Cierva, FJCl2014-19940.

\section{References}

[1] IEA, Energy Technology Perspectives 2012, International Agency of Energy, Paris 2012

[2] Zhuang Z, Li Y, Chen B, Guo J, Chinese kang as a domestic heating system in rural northern China - A review, Energy Build., 41 (2009), pp. 111-119

[3] Basaran T, Ilken Z, Thermal analysis of the heating system of the Small Bath in ancient Phaselis, Energy and Build., 27 (1998), pp. 1-11

[4] Yeo M, Yang IH, Kim, KW, Historical changes and recent energy saving potential of residential heating in Korea, Energy and Build., 35 (2003), pp. 715-727

[5] Olesen BW, Radiant floor heating in theory and practice, ASHRAE J., 44 (2002), pp. 1926.

[6] Rhee KN, Kim KW, A 50 year review of basic and applied research in radiant heating and cooling systems for the built environment, Build. Environ., 91 (2015), pp. 166-190

[7] Meierhans RA, Room air conditioning by means of overnight cooling of the concrete ceiling, ASHRAE Trans., 102 (1996), pp. 693-697

[8] Olesen BW, De Carli M, Scarpa $M$, Koschenz $M$, Dynamic evaluation of the cooling capacity of thermo-active building systems, ASHRAE Trans., 112 (1) (2006), pp. 350357

[9] Xu X, Wang S, Wang J, Xiao F, Active pipe-embedded structures in buildings for utilizing low-grade energy sources: A review, Energy Build., 42 (2010), pp. 1567-1581

[10]Henze GP, Felsmann C, Kalz DE, Herkel S, Primary energy and comfort performance of ventilation assisted thermo-active building systems in continental climates, Energy Build., 40 (2008), pp. 99-111.

[11]Salvalai G, Pfafferott J, Sesana MM, Assessing energy and thermal comfort of different low-energy cooling concepts for non-residential buildings, Energy Convers. Manag., 76 (2013), pp. 332-341

[12] Antonopoulos KA, Vrachopoulos M, Tzivanidis C, Experimental and theoretical studies of space cooling using ceiling-embedded piping, Appl. Therm. Eng., 17 (1997), pp. 351367

[13]Yu T, Heiselberg P, Lei B, Pomianowski M, Validation and modification of modeling thermally activated building systems (TABS) using EnergyPlus, Build. Simul., 7 (2014), pp. 615-627.

[14]Olesen BW, Sommer K, Dïchting B, Control of slab heating and cooling systems studied by dynamic computer simulations, ASHRAE Trans. 108 (2) (2000), pp. 698-707

[15] Gwerder M, Lehmann B, Tödtli J, Dorer V, Renggli F, Control of thermally-activated building systems (TABS), Appl. Energy., 85 (2008), pp. 565-581

[16] Lim J-H, Song J-H, Song S-Y, Development of operational guidelines for thermally activated building system according to heating and cooling load characteristics, Appl. Energy., 126 (2014), pp. 123-135 
[17] Xu X, Yu J, Wang S, Wang J, Research and application of active hollow core slabs in building systems for utilizing low energy sources, Appl. Energy., 116 (2014), pp. 424435

[18] Zhao K, Liu XH, Jiang Y, Application of radiant floor cooling in large space buildings - A review, Renew. Sustain. Energy Rev., 55 (2016), 1083-1093

[19] Tomasi R, De Carli M, A critical review on heat exchange coefficients between heated and cooled horizontal surfaces and room, In: Proceedings of the $11^{\text {th }}$ Roomvent International Conference, May 2009 (Korea), pp. 233-240

[20] Novoselac A, Srebric J, A critical review on the performance and design of combined cooled ceiling and displacement ventilation systems, Energy and Build., 34 (2002), pp. 497-509

[21] Olesen BW, Bonnefoi F, Michel E, De Carli M, Heat exchange coefficient between floor surface and space by floor cooling - theory or a question of definition, ASHRAE Trans., 106 (1) (2000), pp. 684-694

[22] Feustel HE, Stetiu C, Hydronic radiant cooling - preliminary assessment, Energy Build., 22 (1995), pp. 193-205

[23] Raftery P, Lee KH, Webster T, F. Bauman, Performance analysis of an integrated UFAD and radiant hydronic slab system, Appl. Energy., 90 (2012), pp. 250-257

[24] Park SH, Chung WJ, Yeo MS, Kim KW, Evaluation of the thermal performance of a Thermally Activated Building System (TABS) according to the thermal load in a residential building, Energy Build., 73 (2014), pp. 69-82

[25] ASHRAE, ANSI/ASHRAE Standard 62: Ventilation for acceptable indoor quality, America Society of heating, refrigerating and air-conditioning engineers Inc., Atlanta, GA, 2004

[26] ISO 16814:2008 - Building environment design - Indoor air quality - Methods of expressing the quality of indoor air for human occupancy, International Organization of Standardization, 2008

[27] Olesen BW, Radiant heating and cooling by embedded water-based systems, Lingby, Denmark (2007)

[28] Corgnati SP, Perino M, Fracastoro GV, Nielsen PV, Experimental and numerical analysis of air and radiant cooling systems in offices, Build. Environ., 44 (2009), pp. 801-806

[29] Halawa E, van Hoof J, Soebarto V, The impacts of the thermal radiation field on thermal comfort, energy consumption and control-A critical overview, Renew. Sustain. Energy Rev., 37 (2014), pp. 907-918

[30] Tian Z, Love JA, Energy performance optimization of radiant slab cooling using building simulation and field measurements, Energy Build., 41 (2009), pp. 320-330

[31] Medhat A. Fahim, Tropical modelling of concrete-core-radiant-cooling system, In: 9th International Conference on Heat Transfer, Fluid Mechanics and Thermodynamics, Malta, $16^{\text {th }}-18^{\text {th }}$ July 2012 , pp. $1799-1806$

[32] Olesen BW, Operation and control of thermally activated slab heating and cooling systems, Lingby, Denmark (2007)

[33] Ma P, Wang L-S, Guo N, Modeling of TABS-based thermally manageable buildings in Simulink, Appl. Energy., 104 (2013), pp. 791-800 
[34] Tödtli J, Gwerder M., Lehmann Beat, Renggli F, Dorer V., Integrated design of thermally activated buildings systems and of their control, In: $9^{\text {th }}$ REHVA World Congress for Building Technologies - CLIMA 2007, Helsinki, $10^{\text {th }}-14^{\text {th }}$ June 2007

[35] Ma P, Wang L-S, Guo N, Modeling of hydronic radiant cooling of a thermally homeostatic building using a parametric cooling tower, Appl. Energy., 127 (2014), pp. 172-181

[36] Lehmann B, Dorer V, Gwerder M, Renggli F, Tödtli J, Thermally activated building systems (TABS): Energy efficiency as a function of control strategy, hydronic circuit topology and (cold) generation system, Appl. Energy., 88 (2011), pp. 180-191

[37] Kolarik J, Toftum J, Olesen BW, Jensen KL, Simulation of energy use, human thermal comfort and office work performance in buildings with moderately drifting operative temperatures, Energy Build., 43 (2011), pp. 2988-2997

[38] Shin MS, Rhee KN, Ryu SR, Yeo MS, Kim KW, Design of radiant floor heating panel in view of floor surface temperatures, Build. Environ., 92 (2015), pp. 559-577

[39] Antonopoulos KA, Democritou F, Periodic steady-state heat transfer in cooling panels, Int. J. Heat Fluid Flow., 14 (1993), pp. 94-100

[40] Feng JD, Schiavon S, Bauman F, Cooling load differences between radiant and air systems, Energy Build., 65 (2013), pp. 310-321

[41] Ren MJ, Wright JA, A ventilated slab thermal storage system model, Build. Environ., 33 (1998), pp. 43-52

[42] Krzaczek M, Kowalczuk Z, Thermal Barrier as a technique of indirect heating and cooling for residential buildings, Energy Build., 43 (2011), pp. 823-837

[43]Chuangchid P, Krart $M$, Foundation heat loss from heated concrete slab-on -grade floors, Build. Environ., 36 (2001), pp. 637-655

[44]Holopainen R, Tuomaala P, Piippo J, Uneven gridding of thermal nodal networks in floor heating simulations, Energy Build., 39 (2007), pp. 1107-1114

[45]Song G-S, Buttock responses to contact with finishing materials over the ONDOL floor heating system in Korea, Energy Build., 37 (2005), pp. 65-75

[46] Laouadi A, Development of a radiant heating and cooling model for building energy simulation software, Build. Environ., 39 (2004), pp. 421-431

[47] Cho S-H, Zaheer-uddin M, An experimental study of multiple parameter switching control for radiant floor heating systems, Energy., 24 (1999), pp. 433-444

[48] Lim J-H, Kim Y-Y, Yeo M-S, Kim K-W, A comparative study on the control of the radiant floor cooling system, In: 7th REHVA World Congress and Clima 2000, Napoli, $15^{\text {th }}-18^{\text {th }}$ September 2001

[49] Chen TY, Application of adaptive predictive control to a floor heating system with a large thermal lag, Energy Build., 34 (2002), pp. 45-51

[50] Cho SH, Zaheer-uddin M, Predictive control of intermittently operated radiant floor heating systems, Energy Convers. Manag., 44 (2003), pp. 1333-1342

[51] Lim J-H, Yeo M-S, Kim K-W, A study on the application of the radiant floor cooling system integrated with a dehumidification system, In: $8^{\text {th }}$ International IBPSA Conference, Eindhoven, $11^{\text {th }}-14^{\text {th }}$ August 2003

[52] Sourbron M, De Herdt R, Van Reet T, Van Passel W, Baelmans M, Helsen L, Efficiently produced heat and cold is squandered by inappropriate control strategies: A case study, Energy Build., 41 (2009), pp. 1091-1098 
[53] Jin X, Zhang X., Luo $Y, A$ calculation method for the floor surface temperature in radiant floor system, Energy Build., 42 (2010), pp. 1753-1758

[54] De Carli $\mathrm{M}$, Tonon $\mathrm{M}$, Effect of modelling solar radiation on the cooling performance of radiant floors, Sol. Energy., 85 (2011), pp. 689-712

[55] Zhang L, Liu X-H, Jiang $Y$, Simplified calculation for cooling/heating capacity, surface temperature distribution of radiant floor, Energy Build., 55 (2012), pp. 397-404

[56] Li Q, Chen C, Zhang $Y$, Lin J, Ling H, Ma Y, Analytical solution for heat transfer in a multilayer floor of a radiant floor system, Build. Simul., 7 (2013), pp. 207-216

[57] Li Q, Chen C, Zhang Y, Lin J, Ling H, Simplified thermal calculation method for floor structure in radiant floor cooling system, Energy Build., 74 (2014), pp. 182-190

[58]Olesen BW, Possibilities and limitations of radiant floor cooling, ASHRAE Trans., 103 (1997), pp. 42-48

[59]Jin X, Zhang X, Luo Y, Cao R, Numerical simulation of radiant floor cooling system: The effects of thermal resistance of pipe and water velocity on the performance, Build. Environ., 45 (2010), pp. 2545-2552

[60]Lim J-H, Jo J-H, Kim Y-Y, Yeo M-S, Kim K-W, Application of the control methods for radiant floor cooling system in residential buildings, Build. Environ., 41 (2006), pp. 6073

[61]Song D, Kim T, Song S, Hwang S, Leigh S-B, Performance evaluation of a radiant floor cooling system integrated with dehumidified ventilation, Appl. Therm. Eng., 28 (2008), pp. 1299-1311

[62] Kalz DE, Herkel S, Wagner A, The impact of auxiliary energy on the efficiency of the heating and cooling system: Monitoring of low-energy buildings, Energy Build., 41 (2009), pp. 1019-1030

[63] Antonopoulos KA, Tzivanidis C, Numerical solution of unsteady three-dimensional heat transfer during space cooling using ceiling-embedded piping, Energy., 22 (1997), pp. 59-67

[64] Niu J, Kooi Jvd, Indoor climate in rooms with cooled ceiling systems, Build. Environ., 29 (1994), pp. 283-290

[65] Niu J, Kooi Jvd, Rhee Hvd, Energy saving possibilities with cooled-ceiling systems, Energy Build., 23 (1995), pp. 147-158

[66] Imanari T, Omori T, Bogaki K, Thermal comfort and energy consumption of the radiant ceiling panel system: Comparison with the conventional all-air system, Energy Build., 30 (1999), pp. 167-175

[67] Zhang LZ, Niu JL, Indoor humidity behaviors associated with decoupled cooling in hot and humid climates, Build. Environ., 38 (2003), pp. 99-107

[68] Zhang Z, Pate MB, Semi-analytical formulation for heat transfer from structures with embedded tubes, In: The $24^{\text {th }}$ National Heat Transfer Conference ASME-HTD, Pittsburgh, $9^{\text {th }}-12^{\text {th }}$ August 1987,78 pp. $17-25$

[69] Niu J, van der Kooi J, Dynamic simulation of combination of evaporative cooling with cooled ceiling systems for office room cooling, In: Building Simulation '93 - Third Int. Conf., Adelaide, 1993

[70] Ferkl L, Šyroky J, Ceiling radiant cooling: Comparison of ARMAX and subspace identification modelling methods, Build. Environ., 45 (2010), pp. 205-212 
[71] Jeong JW, Mumma SA, Ceiling radiant cooling panel capacity enhanced by mixed convection in mechanically ventilated spaces, Appl. Therm. Eng., 23 (2003), pp. 22932306

[72]Mumma SA, Chilled ceiling in parallel with dedicated outdoor air systems: addressing the concerns of condensation, capacity, and cost, ASHRAE Trans., 108 (2002), pp. 220231

[73]Prívara S, Široký J, Ferkl L, Cigler J, Model predictive control of a building heating system: The first experience, Energy Build., 43 (2011), pp. 564-572

[74]Prívara S, Cigler J, Váňa Z, Oldewurtel F, Žáčeková E, Use of partial least squares within the control relevant identification for buildings, Control Eng. Pract., 21 (2013), pp. 113121

[75]Antonopoulos KA, Analytical and numerical heat transfer in cooling panels, Int. J. Heat Mass Transf., 35 (1992), pp. 2777-2782

[76]Tye-Gingras $M$, Gosselin L, Investigation on heat transfer modelling assumptions for radiant panels with serpentine layout, Energy and Build., 43 (2011), pp. 1598-1608

[77]Tye-Gingras M, Gosselin L, Comfort and energy consumption of hydronic heating radiant ceilings and walls based on CFD analysis, Build. and Environ., 54 (2012), 1-13

[78]De Carli M, Scarpa M, Tomasi R, Zarrella A, DIGITHON: A numerical model for the thermal balance of rooms equipped with radiant systems, Build. Environ., 57 (2012), pp. 126-144

[79] Stetiu C, Energy and peak power savings potential of radiant cooling systems in US commercial buildings, Energy Build., 30 (1999), pp. 127-138

[80] Feng J, Chuang F, Borrelli F, Bauman F, Model predictive control of radiant slab systems with evaporative cooling sources, Energy Build. 87, (2014), pp. 199-210

[81] Zmeureanu R, Fazio $P$, Thermal performance of a hollow core concrete floor system for passive cooling, Build. Environ., 23 (1988), pp. 243-252

[82] Chae YT, Strand RK, Modeling ventilated slab systems using a hollow core slab: Implementation in a whole building energy simulation program, Energy Build., 57 (2013), pp. 165-175

[83] Russell MB, Surendran PN, Influence of active heat sinks on fabric thermal storage in building mass, Appl. Energy., 70 (2001), pp. 17-33

[84] Huchtemann K, Müller D, Combined simulation of a deep ground source heat exchanger and an office building, Build. Environ., 73 (2014), pp. 97-105

[85] Schmelas M, Feldmann T, Bollin E, Adaptive predictive control of thermo-active building systems (TABS) based on a multiple regression algorithm, Energy Build., 103 (2015), pp. 14-28

[86]Sourbron M, Verhelst C, Helsen L, Building models for model predictive control of office buildings with concrete core activation, J. Build. Perf. Sim.,6 (2013), pp. 175-198

[87] Liu K, Tian Z, Zhang C, Ding Y, Wang W, Establishment and validation of modified startype RC-network model for concrete core cooling slab, Energy Build., 43 (2011), pp. 2378-2384

[88] Koschenz M, Dorer V, Interaction of an air system with concrete core conditioning, Energy Build., 30 (1999), pp. 139-145 
[89] Güntensperger W, Gwerder m, Haas A, Lehmann B, Renggli F, Tödtli J, Control of concrete core conditioning systems, In: $8^{\text {th }}$ REHVA World Congress for Building Technologies, Lausanne, $9^{\text {th }}-12^{\text {th }}$ October 2005

[90] Lehmann B, Dorer V, Koschenz M, Application range of thermally activated building systems tabs, Energy Build., 39 (2007), pp. 593-598

[91] Pahud D, Belliardi M, Caputo P, Geocooling potential of borehole heat exchangers' systems applied to low energy office buildings, Renew. Energy., 45 (2012), pp. 197-204

[92] Kalz DE, Pfafferott J, Herkel S, Wagner A, Energy and efficiency analysis of environmental heat sources and sinks: In-use performance, Renew. Energy., 36 (2011), pp. 916-929

[93] Gwerder M, Tödtli J, Lehmann B, Dorer V, Güntensperger W, Renggli F, Control of thermally activated building systems (TABS) in intermittent operation with pulse width modulation, Appl. Energy., 86 (2009), pp. 1606-1616

[94] Rijksen DO, Wisse CJ, van Schijndel AWM, Reducing peak requirements for cooling by using thermally activated building systems, Energy Build., 42 (2010), pp. 298-304

[95] Renggli F, Gwerder M, Tödli J, Lehmann B, Dorer V, Effect of the hydraulic piping topology on energy demand and comfort in buildings with TABS, In: $9^{\text {th }}$ REHVA World Congress for Building Technologies - CLIMA 2007, Helsinki, 10 $0^{\text {th }}-14^{\text {th }}$ June 2007

[96] Gwerder M, Lehmann, Tödli J, Dorer V, Renggli, Control of thermally-activated building systems (TABS), In: $9^{\text {th }}$ REHVA World Congress for Building Technologies CLIMA 2007, Helsinki, $10^{\text {th }}-14^{\text {th }}$ June 2007

[97] Tian Z, Duan B, Niu X, Hu Q, Niu J, Establishment and experimental validation of a dynamic heat transfer model for concrete radiant cooling slab based on reaction coefficient method, Energy Build., 82 (2014), pp. 330-340

[98] Hauser G, Kempkes C, Olesen B, Computer simulation of hydronic heating/cooling system with embedded pipes, ASHRAE Trans., 106 (2000), pp. 702-712

[99] Sarbu I, Sebarchievici C, A study of the performances of low-temperature heating systems, Energy Effic., 8 (2015), pp. 609-627

[100] Meierhans RA, Slab cooling and earth coupling, ASHRAE Trans., 99 (1993), pp. 511-518

[101] Babiak J, Minárova $M$, Olesen BW, What is the effective thickness of a thermally activated concrete slab, In: $9^{\text {th }}$ REHVA World Congress for Building Technologies - CLIMA 2007, Helsinki, $10^{\text {th }}-14^{\text {th }}$ June 2007

[102] Weitzmann P, Modelling building integrated heating and cooling systems (Thesis), Lingby 2004

[103] Xie J, Zhu $Q, X u X$, An active pipe-embedded building envelope for utilizing low-grade energy sources, J. Cent. South Univ., 19 (2012), pp. 1663-1667

[104] Xu X, Zhu Q, Jinbo W, Xiao F, Study of Dynamic Thermal Performance of Active Pipe-Embedded building envelopes based on frequency-domain finite difference method, Trans. Electr. Electron, Circuits Syst. , 3 (2013), pp. 65-72

[105] Zhu Q, Xu X, Wang J, Xiao F, Development of dynamic simplified thermal models of active pipe-embedded building envelopes using genetic algorithm, Int. J. Therm. Sci., 76 (2014), pp. 258-272 
[106] Zhu Q, Xu X, Gao J, Xiao F, A semi-dynamic model of active pipe-embedded building envelope for thermal performance evaluation, Int. J. Therm. Sci., 88 (2015), pp. $170-179$

[107] Doležel $M$, Alternative way of thermal protection by thermal barrier, In: International Conference on Buildings and Environment EnviBUILD 2013 , Bratislava, $17^{\text {th }}$ October 2013

[108] Krzaczek M, Kowalczuk Z, Gain Scheduling Control applied to Thermal Barrier in systems of indirect passive heating and cooling of buildings, Control Eng. Pract., 20 (2012), pp. 1325-1336

[109] Venko S, Pavlovič E, Vidrih B, Arkar C, Medved S, An experimental study of mixed convection over various thermal activation lengths of vertical TABS, Energy Build., 98 (2015), pp. 151-160

[110] Bojić $M$, Cvetković $D$, Miletić $M$, Malešević J, Boyer H, Energy, cost, and CO2 emission comparison between radiant wall panel systems and radiator systems, Energy Build., 54 (2012), pp. 496-502

[111] Schmidt D, Jóhannesson G, Approach for modelling of hybrid heating and cooling components with optimised RC networks, Nord. J. Build. Phys., 3 (2002)

[112] Raimondo D, Olesen BW, Corgnati SP, Field test of a thermal active building system (tabs) in an office building, Proceedings of BS2013, (2013), pp. 2527-2534

[113] Dossi FC, De Carli M, Del Bianco R, Fellin F, Tonon M, Zecchin R, A pilot project for a low energy building equipped with thermal slabs, heat pump and ground heat storage, In: Proceeding of Building Simulation Conferences, Eindhoven, $11^{\text {th }}-14^{\text {th }}$ August 2003

[114] Fellin F, Sommer K, Study of low energy office building with thermal slabs and ground coupled heat pump, In: Proceedings 58-th ATI 2003 Conference, Padua, $9^{\text {th }}-12^{\text {th }}$ September2003

[115] Weber T, Multipoint RC-Networks with an application in thermally activated building component systems (TABS), KTH Royal Institute of Technology, (2005)

[116] Weber T, Energy performance of buildings / methodologies for experimental verification (Thesis), Stockholm 2004

[117] Weber T, Jóhannesson G, Koschenz M, Lehmann B, Baumgartner T, Validation of a FEM-program (frequency-domain) and a simplified RC-model (time-domain) for thermally activated building component systems (TABS) using measurement data, Energy Build., 37 (2005), pp. 707-724

[118] Weber T, Jóhannesson G, An optimized RC-network for thermally activated building components, Build. Environ., 40 (2005), pp. 1-14

[119] Schmidt D, Jóhannesson G., Optimised RC Networks Incorporated within Macro-Elements for Modelling Thermally Activated Building Constructions, Nord. J. Build. Phys. 3 (2004), pp. 72-100

[120] Arteconi A, Costola D, Hoes P, Hensen JLM, Analysis of control strategies for thermally activated building systems under demand side management mechanisms, Energy Build., 80 (2014), pp. 384-393

[121] De Wit AK, Wisse CJ, Hydronic circuit topologies for thermally activated building systems - Design questions and case study, Energy Build., 52 (2012), pp. 56-67 
[122] Heier J, Bales C, Martin V, Combining thermal energy storage with buildings - A review, Renew. Sustain. Energy Rev., 42 (2015), pp. 1305-1325

[123] Perino $M$ editor, State of art review Responsive building elements, IEA Annex 44, Aalborg (2008)

[124] Saelens D, Parys W, Baetens R, Energy and comfort performance of thermally activated building systems including occupant behavior, Build. Environ., 46 (2011), pp. 835-848

[125] Stojanovic B, Janevski J, Mitkovic P, Stojanovic M, Ignjatovic $M$, Thermally activated building systems in context of increasing building energy efficiency, Therm. Sci., 18 (2014), pp. 1011-1018

[126] Behrendt BM, Raimondo D, Zhang Y, Schwarz S, Christensen J.E, Olesen BW, A system for the comparison of tools for the simulation of water-based radiant heating and cooling systems, In: Proceedings of Building Simulation Conference, Sidney, $14^{\text {th }}$ $16^{\text {th }}$ November 2011

[127] ISO 11855: Design. dimensioning, installation and control of embedded radiant heating and cooling systems, (2012)

[128] UNE-EN 1264: Water based surface heating and cooling systems, (2013)

[129] UNE-EN 15377: Heating systems in buildings - Design of embedded water based surface heating and cooling systems, (2009)

[130] American Society of Heating, Refrigerating and Air-Conditioning Engineers, ASHRAE Handbook Fundamentals, (2013)

[131] Babiak J, Olesen BW, Petrás D, Low temperature heating and high temperature cooling, REHVA, Brussels (2009)

[132] Bockelman F, Plesser S, Soldaty $H$, Advanced design and operation of GEOTABS buildings: design and operation of GEOTABS, REHVA, Brussels (2013)

[133] UNE-EN ISO 7730: Ergonomics of the thermal environment - Analytical determination and interpretation of thermal comfort using calculation if the PMV and PPD indices and local thermal comfort criteria, (2006)

[134] UNE-EN 15251: Indoor environmental input parameters for design and assessment of energy performance of buildings addressing indoor air quality, thermal environment, lighting and acoustics, (2008)

[135] ASHRAE Standard 55: Thermal environmental conditions for human occupancy, (1992)

[136] Babiak J, Petras D, Olesen BW, Low temperature heating and high temperature cooling embedded water based surface heating and cooling systems, REHVA, Brussels (2008)

[137] De Carli M, Olesen BW, Field Measurements of Thermal Comfort Conditions in Buildings with Radiant Surface Cooling Systems, In: Clima 2000/Napoli 2001 World congress, Naples, $15^{\text {th }}-18^{\text {th }}$ September 2001

[138] Patankar SV, Numerical Heat Transfer and Fluid Flow, New York 1980

[139] Fort K, TYPE 360: Floor Heating and Hypocaust, Transsolar (2001)

[140] Koschenz M, Lehmann B, Thermoaktive Bauteilsysteme tabs, EMP, Duebendorf (2000)

[141] Larsen SF, Filippín C, Lesino G, Transient simulation of a storage floor with a heating/cooling parallel pipe system, Build. Simul., 3 (2010), pp. 105-115 
[142] Simões N, Tadeu A, Transient conduction and convection heat transfer across a multi-layer floor subjected to multiple heat sources, Build. Environ., 41 (2006), pp. 1299-1310

[143] Roumajon J, Modélisation numerique des émissions thermiques, Chaud Froid Plomb., 579 (1996), pp. 55-58

[144] Strand RK, Baumgartner KT, Modeling radiant heating and cooling systems: Integration with a whole-building simulation program, Energy Build., 37 (2005), pp. 389-397

[145] ESP-r, University of Strathclyde, United Kingdom

[146] DOE-2 Building Energy Use and Cost Analysis Software, JJH, United States of America

[147] eQuest Quick Energy Simulation Tool, JJH, United States of America

[148] Clim2000, EDF, France

[149] ESP-r/HOT3000, CANMET Energy Technology Centre, Canada

[150] Strand RK, Pedersen CO, Modeling radiant systems in an integrated heat balance based energy simulation program, ASHRAE Trans., 108 (2002), pp. 979-988

[151] IDA-ICE IDA Indoor Climate and Energy, EQUA Simulation AB, Sweden

[152] IESVE, Integrated Environmental Solutions, United Kingdom

[153] TRNSYS A Transient System Simulation Program, University of Wisconsin, United State of America

[154] Achermann M, Zweifel G, RADTEST - Radiant heating and cooling test cases, IEA (2003)

[155] Braun JE, Reducing energy cost and peak electrical demand through optimal control of building thermal storage, ASHRAE Trans., 96 (1990), pp. 839-848

[156] Afram A, Janabi-Sharifi F, Theory and applications of HVAC control systems - A review of model predictive control (MPC), Build. Environ., 72 (2014), pp. 343-355

[157] Zakula T, Armstrong PR, Norford L, Modeling environment for model predictive control of buildings, Energy and Build., 85 (2014), pp. 549-559 